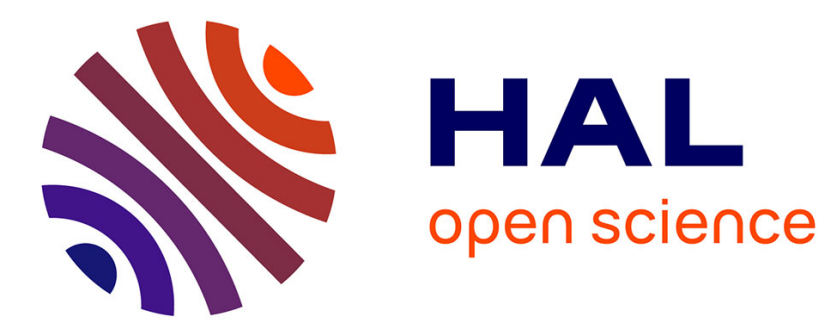

\title{
Ethylene carbonate/cyclic ester random copolymers synthesized by ring-opening polymerization
}

William Guerin, Marion Helou, Martine Slawinski, Jean-Michel Brusson, Jean-François Carpentier, Sophie M. Guillaume

\section{- To cite this version:}

William Guerin, Marion Helou, Martine Slawinski, Jean-Michel Brusson, Jean-François Carpentier, et al. Ethylene carbonate/cyclic ester random copolymers synthesized by ring-opening polymerization. Polymer Photochemistry, 2015, 6 (11), pp.1972-1985. 10.1039/C4PY01660B . hal-01115001

\section{HAL Id: hal-01115001 \\ https://hal-univ-rennes1.archives-ouvertes.fr/hal-01115001}

Submitted on 26 May 2015

HAL is a multi-disciplinary open access archive for the deposit and dissemination of scientific research documents, whether they are published or not. The documents may come from teaching and research institutions in France or abroad, or from public or private research centers.
L'archive ouverte pluridisciplinaire HAL, est destinée au dépôt et à la diffusion de documents scientifiques de niveau recherche, publiés ou non, émanant des établissements d'enseignement et de recherche français ou étrangers, des laboratoires publics ou privés. 
Ethylene Carbonate/Cyclic Ester Random Copolymers Synthesized by Ring-Opening

\section{Polymerization}

William Guerin, ${ }^{a}$ Marion Helou, ${ }^{b}$ Martine Slawinski, ${ }^{b}$ Jean-Michel Brusson, ${ }^{c}$ Jean-François Carpentier $^{a}$ and Sophie M. Guillaume ${ }^{a, *}$

${ }^{a}$ Institut des Sciences Chimiques de Rennes, UMR 6226 CNRS-Université de Rennes 1, Campus de Beaulieu, F-35042 Rennes Cedex, France

${ }^{b}$ Total Raffinage Chimie Feluy, Zone Industrielle Feluy C, B-7181 Seneffe, Belgium

${ }^{c}$ Total S.A., Corporate Science, Tour Michelet A, 24 Cours Michelet - La Défense 10, 92069

Paris La Défense Cedex, France

* Corresponding author: sophie.guillaume@ univ-rennes1.fr 


\section{Table of content}

Ethylene Carbonate/Cyclic Ester Random Copolymers by ROP

$n$<smiles>O=C1CCCCO1</smiles>
EC

L-Lactide, LLA $\beta$-Butyrolactone, $\mathbf{B L}$

$\delta$-Valerolactone, $\mathbf{V I}$ $\varepsilon$-Caprolactone, $\mathbf{C L}$<smiles>CC[C@]12Oc3c(cc(C(C)(C)C)cc3C(C)(C)C)CN1CCN2C</smiles>

[(NNO)ZnEt]/BnOH Bulk, $60^{\circ} \mathrm{C}$<smiles>[Y]C(NC(=O)OC(C)(C)C)C(C)C</smiles>

$\mathrm{x}=0, \mathrm{R}=\mathrm{CH}_{3} \quad \mathbf{P}(\mathbf{E C}-$ co $-\mathbf{L L A})$ $\mathrm{x}=1, \mathrm{R}=\mathrm{CH}_{3} \quad \mathbf{P}(\mathbf{E C}-$ co-BL) $\mathrm{x}=3, \mathrm{R}=\mathrm{H} \quad \mathrm{P}(\mathbf{E C}-$ co-VL) $\mathrm{x}=4, \mathrm{R}=\mathrm{H} \quad \mathbf{P}(\mathbf{E C}-$ co-CL)

Ethylene carbonate copolymers $17-37 \mathrm{~mol} \%$ EC inserted No $\mathrm{CO}_{2}$ loss 


\section{Abstract}

The diaminophenolate and $\beta$-diketiminate zinc complexes $[(\mathrm{NNO}) \mathrm{ZnEt}]\left((\mathrm{NNO})^{-}=2,4\right.$-ditert-butyl-6-\{[(2’-dimethylaminoethyl)-methylamino]methyl $\}$ phenolate $))$ and $\left[\left(\mathrm{BDI}^{\mathrm{iPr}}\right) \mathrm{Zn}\left\{\mathrm{N}\left(\mathrm{SiMe}_{3}\right)_{2}\right\}\right]\left(\mathrm{BDI}^{i \mathrm{Pr}}=\mathrm{CH}\left(\mathrm{CMeNC}_{6} \mathrm{H}_{3}-2,6-i \mathrm{Pr}_{2}\right)_{2}\right)$, respectively, the Lewis acidic triflate salt $\mathrm{Al}(\mathrm{OTf})_{3}$, and the organic guanidine $\mathrm{TBD}$ (= 1,5,7-triazabicyclo[4.4.0]dec-5-ene), combined to a protic source as initiator, typically benzyl alcohol $(\mathrm{BnOH})$, enabled the successful copolymerization of ethylene carbonate (EC) with various cyclic esters such as $\beta$-butyrolactone (BL), $\delta$-valerolactone (VL), $\varepsilon$-caprolactone (CL) or L-lactide (LLA). The random copolymerizations proceeded smoothly under mild operating conditions, preferentially from $[(\mathrm{NNO}) \mathrm{ZnEt}] / \mathrm{BnOH}$ at $60{ }^{\circ} \mathrm{C}$ in toluene within a few hours, affording the corresponding copolymers void of ether units, with $M_{\mathrm{n}, \mathrm{SEC}}$ values in the range $c a$. 6000-93 350 g.mol ${ }^{-1}$ and with unimodal, moderately broad dispersity values $\left(\bigoplus_{\mathrm{M}}=1.3-2.1\right)$. Under the same experimental conditions, the homopolymerization of EC did not proceed. The first EC/BL random copolymers were thus synthesized with up to $26 \mathrm{~mol} \%$ of EC inserted within the polyester, while the second example of $\mathrm{P}(\mathrm{EC}-\mathrm{co}-\mathrm{VL})$ was isolated. $\mathrm{P}(\mathrm{EC}-\mathrm{co}-\mathrm{VL})$, $\mathrm{P}(\mathrm{EC}-\mathrm{co}-\mathrm{CL})$, and $\mathrm{P}(\mathrm{EC}-\mathrm{co}-\mathrm{LLA})$ copolymers were prepared with higher than previously reported EC content, namely 23, 37, and 17 mol\% vs. 10, 31, and 4 mol\%, respectively. In contrast to other catalyst systems, the $\mathrm{Al}(\mathrm{OTf})_{3} / \mathrm{BnOH}$ system promoted $\mathrm{CO}_{2}$ elimination from the copolymers, thereby leading to ether defaults. Microstructural analysis of the copolymers by ${ }^{13} \mathrm{C}\left\{{ }^{1} \mathrm{H}\right\}$ NMR spectroscopy revealed the presence of signals previously never described and possibly arising from consecutive EC units within the random copolymers. Thermal transition temperatures measured by DSC further supported the random nature of these copolymers. 


\section{Introduction}

In the past decade, polycarbonates (PCs) have gained growing industrial and academic interest owing to their properties. Their range of thermal, mechanical and optical characteristics as well as their non-toxicity, biocompatibility, (bio)degradability, and bioresorbability have contributed to promote such polymers at the forefront of both commodity and engineered materials alongside traditional polyesters. Also, recent advances in PCs synthesis have evidenced sustainable and valuable green approaches in compliance with environmental considerations. Chemically speaking, PCs can be rather easily functionalized thus providing tunable polymer materials with further valuable opportunities. Thus, PCs nowadays appear as topical leading candidates for added-value applications in automotive, aircraft, construction, electronic and biomedical materials. ${ }^{1,2,3,4}$

PCs can be prepared according to three distinct synthetic methods, namely i) polycondensation of phosgene, triphosgene, or a dialkyl or diaryl carbonate with an $\alpha, \omega$-diol,,$^{5,6,7,8}$ ii) copolymerization of epoxides with carbon dioxide, ${ }^{9,10,11,12,13,14,15,16,17}$ or iii) ring-opening polymerization (ROP) of a cyclic carbonate monomer. ${ }^{2,18,19,20,21,22,23}$ While the former route does not meet all safety and health requirements for those in PC industry and for the consumers, the more friendly "greener" $\mathrm{CO}_{2}$ /epoxide approach sometimes suffers from incomplete selectivity, resulting in (often detrimental) ether units within the recovered PC and/or formation of cyclic carbonate as co-product. On the other hand, ROP of cyclic carbonates provides a good method towards the synthesis of well-defined PCs with adjustable macromolecular parameters. PCs have thus been produced without $\mathrm{CO}_{2}$ loss through a controlled ROP mediated by (organo)metallic or organic (i.e., metal-free) catalytic systems, enabling fine tuning of the PC molar mass and dispersity $\left(\bigoplus_{\mathrm{M}}=M_{\mathrm{w}} / M_{\mathrm{n}}\right)$ values, as well as end-group fidelity, upon limitation of the undesirable transcarbonatation and other sidereactions. ${ }^{2,18-23}$ 
In this general ROP context, five-membered cyclic carbonates (5CCs) clearly stand apart from their larger $(\geq 6)$ congeners. Indeed, thermodynamics, with ring-opening enthalpies values $\left(\Delta \mathrm{H}^{\circ}\right)$ most often positive, does not favor their polymerizability. ${ }^{22,24,25,26}$ While increasing the reaction temperature can shift the monomer/polymer equilibrium by raising the entropy, thus making the free energy $\left(\Delta \mathrm{G}^{\circ}\right)$ negative, decarboxylation is then generally observed. The homopolymerization of 5CCs is thus rarely controlled and remains difficult to optimize.

Few 5CCs have been ring-open polymerized. To our knowledge, these are limited to ethylene carbonate (EC), ${ }^{27,28,29,30,31,32,33,34,35}$ propylene carbonate (PPC), ${ }^{26,33,36,37,38}$ methyl 4,6$O$-benzylidene-2,3- $O$-carbonyl- $R$-D-glucopyranoside $\quad(\mathrm{MBCG}),{ }^{39,40}$ and cyclohexene carbonate $(\mathrm{CHC}) .{ }^{22,23}$ In the literature, the ROP of EC and PPC are the most documented ones, certainly because of their commercial availability. Although the ceiling temperature of EC and PPC is below $25^{\circ} \mathrm{C}$, these $5 \mathrm{CC}$ s have been polymerized above $100{ }^{\circ} \mathrm{C}$, most likely as the result of $\mathrm{CO}_{2}$ abstraction which makes $\Delta \mathrm{S}^{\circ}$ positive thereby overcoming the positive enthalpy, so that the polymerization then becomes thermodynamically possible. ${ }^{26-27}$ Various initiators ${ }^{41}$ have been used in the ROP of EC and PPC, but these reactions always led to partial or complete decarboxylation. ${ }^{26-38}$ On the other hand, the homopolymerization of MBCG and CHC proceeded without elimination of $\mathrm{CO}_{2}$ and afforded better-defined polymers. ${ }^{22,23,39,40,42}$ For the latter two monomers, ROP actually occurs as the result of the favorable ring-strain of the glucopyranosyl and cyclohexyl moiety fused onto the 5CC moiety, respectively, which sufficiently destabilizes the monomer. The PCs thus obtained (poly(MBCG): $M_{\mathrm{n}, \mathrm{SEC}}$ up to $20^{\circ} 200 \mathrm{~g} \cdot \mathrm{mol}^{-1}, \bigoplus_{\mathrm{M}}=1.8$; poly $(\mathrm{CHC}): M_{\mathrm{n}, \mathrm{NMR}}$ up to $\left.17^{\circ} 000 \mathrm{~g} \cdot \mathrm{mol}^{-1}, \bigoplus_{\mathrm{M}}=c a \cdot 1.2\right)$ generally featured higher molar mass values as compared to those derived from the ROP of EC or PPC $\left(M_{\mathrm{n}, \mathrm{SEC}}\right.$ commonly in the range 300-9000, up to $\left.22100 \mathrm{~g} \cdot \mathrm{mol}^{-1}, \bigoplus_{\mathrm{M}}=1.14-3.1\right)$. 
Also, EC has been successfully copolymerized by ROP with a few other cyclic monomers, namely $\varepsilon$-caprolactone (CL), $\delta$-valerolactone (VL), L-lactide (LLA), and 2,2-dimethyltrimethylene carbonate (DTC). ${ }^{43,44,45,46,47,48,49,50,51}$ The initiating systems always ${ }^{52}$ involved rare earth complexes: $\quad\left[\left(\mathrm{C}_{5} \mathrm{Me}_{5}\right)_{2} \mathrm{SmMe}(\mathrm{THF})\right], \quad\left[\left(\mathrm{C}_{9} \mathrm{H}_{7}\right)_{2} \mathrm{Sm}(\mathrm{THF})_{1.5}\right]$, $\left[\left(\mathrm{C}_{13} \mathrm{H}_{9}\right)_{2} \mathrm{Sm}(\mathrm{THF})_{2}\right],\left[\left\{\left(\mathrm{Me}_{3} \mathrm{Si}\right)_{2} \mathrm{~N}\right\}_{2} \mathrm{Sm}(\mathrm{THF})_{2}\right],\left[\mathrm{SmI}_{2}(\mathrm{THF})\right], \mathrm{SmI}_{2} / \mathrm{Sm}$, or $\mathrm{Ln}(\mathrm{DBMP})_{3}(\mathrm{Ln}$ $=\mathrm{La}, \mathrm{Nd}, \mathrm{Sm}, \mathrm{Dy} ; \mathrm{DBMP}=2,6$-di-tert-butyl-4-methylphenolate). Simultaneous ${ }^{53}$ and more rarely sequential ${ }^{43}$ copolymerizations were carried out in toluene at room temperature except for LLA (in bulk at $50{ }^{\circ} \mathrm{C}$ ), over a few hours-to-several days. ${ }^{43-50}$ The extent of decarboxylation was observed to depend on the initial EC/comonomer ratio. For instance, no $\mathrm{CO}_{2}$ abstraction was detected in the synthesis of random EC/CL copolymers starting from a EC/CL molar ratio of 60:40, while partial (14\%) decarboxylation occurred at 70:30. ${ }^{44}$ The amount of EC incorporated in these various EC copolymers remained in the range 4-31 mol\% and affected the thermo-mechanical properties of the copolymers. ${ }^{47}$ Degradability of poly(ECco-CL) and poly(EC-co-VL) was also shown to be much improved upon incorporation of EC units along the polyester chain. ${ }^{44}$

Thus, although 5CCs such as EC and glycerol carbonate are industrially available in large volumes, their valorization by ROP still remains challenging. Very few examples of the successful homopolymerization or copolymerization by ring-opening approach have been established, even less with optimized controlled activity and productivity. ${ }^{22,26,33,36-38}$ EC random copolymers remain limited and are, so far, only accessible from rare earth-based catalysts.

In this contribution, we report the synthesis of EC/cyclic esters copolymers from the controlled ROP of EC and $\beta$-butyrolactone (BL), VL, CL or LLA, using the diaminophenolate or $\beta$-diketiminate zinc complex, $[(\mathrm{NNO}) \mathrm{ZnEt}]\left((\mathrm{NNO})^{-}=2,4\right.$-di-tert-butyl6- $\left\{\left[\left(2^{\prime}\right.\right.\right.$-dimethylaminoethyl)-methylamino $]$ methyl $\}$ phenolate $\left.)\right),{ }^{54}$ or $\left[\left(\mathrm{BDI}^{i \mathrm{Pr}}\right) \mathrm{Zn}\left\{\mathrm{N}\left(\mathrm{SiMe}_{3}\right)_{2}\right\}\right]$ 
$\left(\mathrm{BDI}^{i \mathrm{Pr}}=\mathrm{CH}\left(\mathrm{CMeNC}_{6} \mathrm{H}_{3}-2,6-i \mathrm{Pr}_{2}\right)_{2}\right),{ }^{55,56}$ respectively, the Lewis acidic salt $\mathrm{Al}(\mathrm{OTf})_{3}(\mathrm{OTf}=$ $\mathrm{O}_{3} \mathrm{SCF}_{3}$ ), or the organocatalyst TBD (1,5,7-triazabicyclo[4.4.0]dec-5-ene), combined to a protic source as initiator, typically benzyl alcohol $(\mathrm{BnOH})(\mathrm{Scheme} 1)$. Well-defined random copolymers featuring as much as $38 \mathrm{~mol} \%$ of EC were thus prepared with the zinc-based systems, and thoroughly characterized by ${ }^{1} \mathrm{H},{ }^{13} \mathrm{C}$ NMR, SEC and DSC analyses.

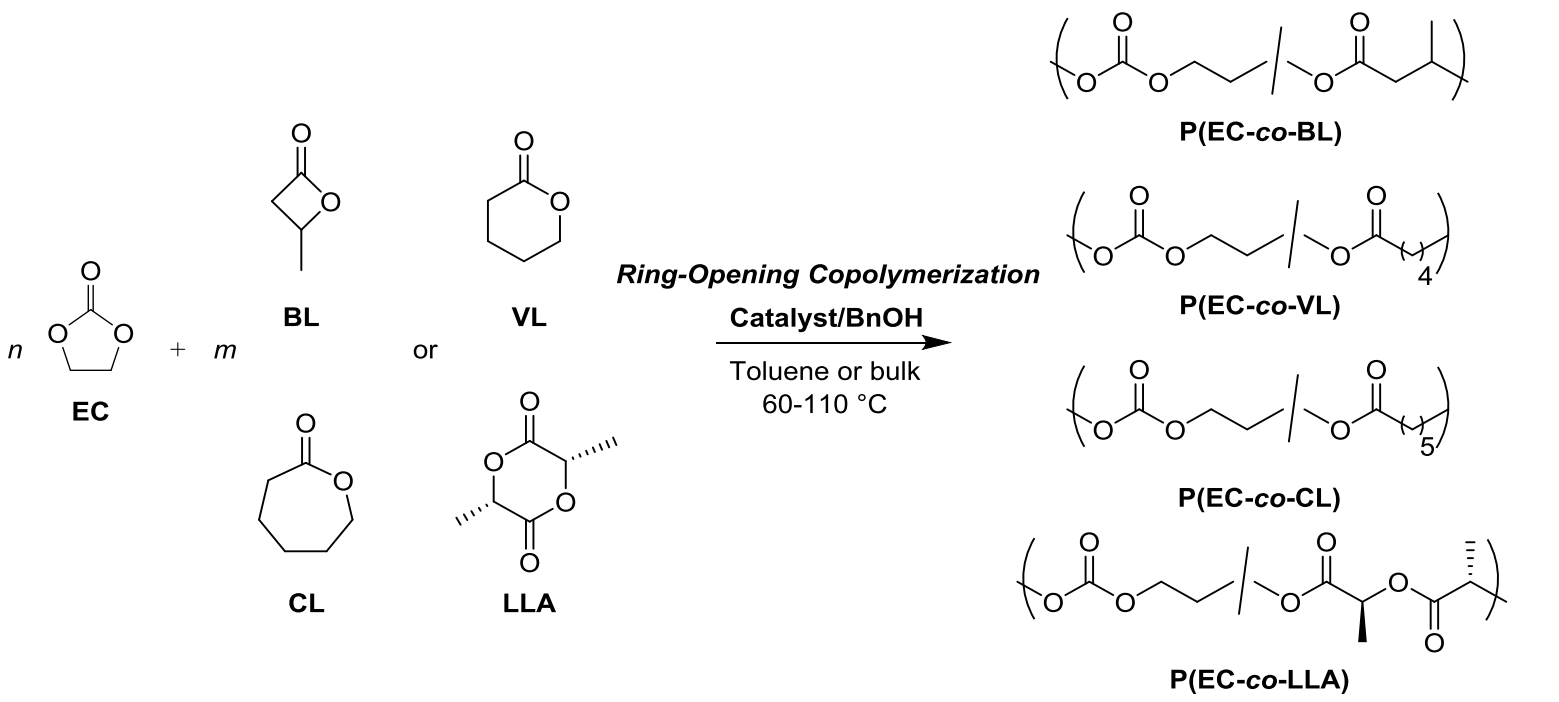

(pre)catalyst:
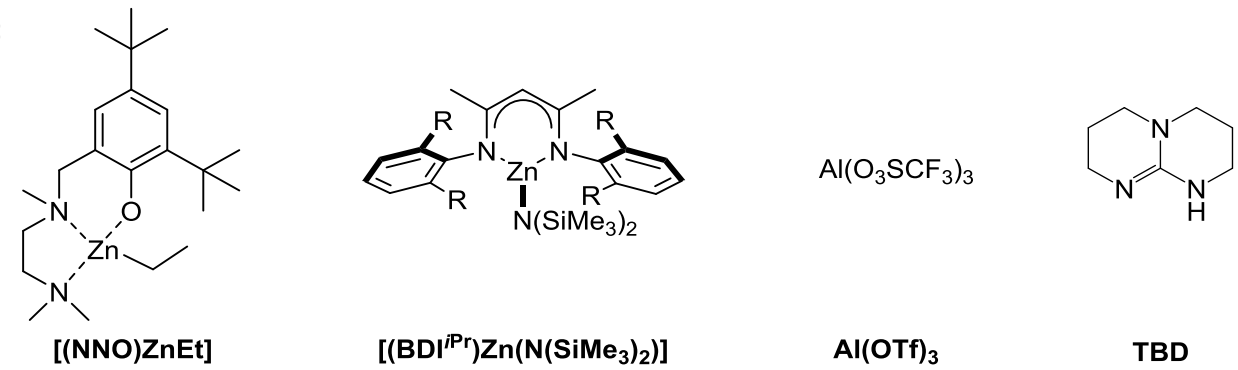

[(NNO)ZnEt]

$\left.\left[(\mathrm{BDI})^{\mathrm{Pr}}\right) \mathrm{Zn}\left(\mathrm{N}\left(\mathrm{SiMe}_{3}\right)_{2}\right)\right]$

(OTf) 3

TBD

Scheme 1. Synthesis of PEC-co-polyester by ring-opening copolymerization of EC with BL, VL, CL or LLA.

\section{Experimental section}

\section{Materials}

All polymerizations were performed under inert atmosphere (argon) using standard Schlenk, vacuum line, and glovebox techniques. Racemic $\beta$-butyrolactone (BL) (>95\%, TCI 
Chemicals), $\delta$-valerolactone (98\%, VL, Alpha Aesar) and $\varepsilon$-caprolactone (CL, 99.5\%, Aldrich) were purified (twice for BL) by distillation from $\mathrm{CaH}_{2}$ and stored under argon. L-Lactide (LLA; technical grade, Total Petrochemicals) was purified by crystallization from a hot $\left(80^{\circ} \mathrm{C}\right)$ concentrated solution in 2-propanol, followed by two subsequent crystallizations in toluene at $105{ }^{\circ} \mathrm{C}$, and finally stored under argon at room temperature. The commercial PEC sample $\left(\mathrm{QPAC}^{\circledR} 25 ; M_{\mathrm{n}}=250000 \mathrm{~g} \cdot \mathrm{mol}^{-1}, \bigoplus_{\mathrm{M}}=1.9\right.$; Figures S1-S2) was obtained from Empower Materials. Benzyl alcohol (Acros) was distilled over Mg turnings under argon atmosphere and kept over 3-4 $\AA$ activated molecular sieves. $\mathrm{CDCl}_{3}$ was dried over a mixture of 3 and $4 \AA$ molecular sieves. $\left[\left(\mathrm{BDI}^{\mathrm{iPr}}\right) \mathrm{Zn}\left\{\mathrm{N}\left(\mathrm{SiMe}_{3}\right)_{2}\right\}\right]^{55,56}$ and $[(\mathrm{NNO}) \mathrm{ZnEt}],{ }^{54}$ were synthesized following the literature procedures. 1,5,7-Triazabicyclo[4.4.0]dec-5-ene (TBD) (98\%, Aldrich), $\mathrm{Al}(\mathrm{OTf})_{3}$ (Aldrich) and all other reagents were used as received.

\section{Instrumentation and measurements}

${ }^{1} \mathrm{H}(500$ and $400 \mathrm{MHz})$ and ${ }^{13} \mathrm{C}\left\{{ }^{1} \mathrm{H}\right\}(125 \mathrm{MHz})$ NMR spectra were recorded on Bruker Avance AM 500 and Ascend 400 spectrometers at $25^{\circ} \mathrm{C}$ and were referenced internally relative to $\mathrm{SiMe}_{4}(\delta 0 \mathrm{ppm})$ using the residual solvent resonances.

Size-exclusion chromatography (SEC) giving number-average molar mass $\left(M_{\mathrm{n}, \mathrm{SEC}}\right)$ and dispersity $\left(\bigoplus_{\mathrm{M}}=M_{\mathrm{w}} / M_{\mathrm{n}}\right)$ values of the polymers was carried out in THF at $30{ }^{\circ} \mathrm{C}$ (flow rate $1.0 \mathrm{~mL} \cdot \mathrm{min}^{-1}$ ) on a Polymer Laboratories PL50 apparatus equipped with a refractive index detector and a set of two ResiPore Mixed E $300 \times 7.5 \mathrm{~mm}$ columns. The polymer samples were dissolved in THF $\left(2 \mathrm{mg} \cdot \mathrm{mL}^{-1}\right)$. All elution curves were calibrated with polystyrene standards; $M_{\mathrm{n}, \mathrm{SEC}}$ values of the PBLs, PVLs and PEC copolymers were uncorrected for the potential difference in hydrodynamic radius vs. polystyrene. The SEC traces of the copolymers all exhibited a unimodal symmetrical peak.

Monomer conversions were calculated from ${ }^{1} \mathrm{H}$ NMR spectra of the crude polymer samples by using the integration (Int.) ratio Int.PEC/[Int.PEC + Int.EC] of the methylene 
hydrogens $\left(-\mathrm{OCH}_{2} \mathrm{CH}_{2} \mathrm{O}, \delta_{\mathrm{PEC}} 3.66 \mathrm{ppm}, \delta_{\mathrm{EC}} 4.35 \mathrm{ppm}\right)$ of EC, Int.PBL/[Int.PBL + Int.BL] of the methine hydrogen $\left(-\mathrm{OCH}\left(\mathrm{CH}_{3}\right) \mathrm{CH}_{2}, \delta_{\mathrm{PBL}} 5.25 \mathrm{ppm}, \delta_{\mathrm{BL}} 4.66 \mathrm{ppm}\right)$ of BL, Int.PVL/[nt.PVL + Int.vL] of the methylene hydrogens $\left(-\mathrm{OCH}_{2}, \delta_{\mathrm{PVL}} 4.05 \mathrm{ppm}, \delta_{\mathrm{VL}} 4.20 \mathrm{ppm}\right)$ of VL, Int.PCL/[nt.PCL + Int.CL] of the methylene hydrogens $\left(-\mathrm{OCH}_{2}, \delta_{\mathrm{PCL}} 4.04 \mathrm{ppm}, \delta_{\mathrm{CL}} 4.19 \mathrm{ppm}\right)$ of $\mathrm{CL}$, and Int.PLLA/[Int.PLLA+Int.LLA] of the methine hydrogen $\left(\mathrm{OCHCH}_{3} \mathrm{C}(\mathrm{O}), \delta_{\text {PLLA }} 5.18\right.$ ppm, $\left.\delta_{\text {LLA }} 5.05 \mathrm{ppm}\right)$ of LLA. Note that the actual chemical shifts varied slightly with the nature of the copolymer. The amount of EC inserted was determined by ${ }^{1} \mathrm{H}$ NMR analysis of the precipitated polymer samples, using the intensity ratio of the signals corresponding to the EC $\left(-\mathrm{C}(\mathrm{O}) \mathrm{OCH}_{2} \mathrm{CH}_{2} \mathrm{O}\right)$ and to the PHB $\left(\left(-\mathrm{C}(\mathrm{O}) \mathrm{OCH}_{2} \mathrm{CH}-\right)\right.$, PVL $\left(-\mathrm{C}(\mathrm{O}) \mathrm{OCH}_{2} \mathrm{CH}_{2}-\right)$, PCL $\left(-\mathrm{C}(\mathrm{O}) \mathrm{OCH}_{2} \mathrm{CH}_{2}-\right)$, or PLLA (-OCH( $\left.\mathrm{CH}_{3}\right) \mathrm{C}(\mathrm{O})-$ ) hydrogens.

Molar mass values were not determined by ${ }^{1} \mathrm{H}$ NMR analysis because the chain-end signal was not always observed/identified, especially in the absence of added $\mathrm{BnOH}$ chain transfer agent.

Differential scanning calorimetry (DSC) analyses were performed on a Setaram DSC 131 apparatus calibrated with indium at a rate of $10{ }^{\circ} \mathrm{C} \cdot \mathrm{min}^{-1}$, under continuous flow of helium (25 $\mathrm{mL} \cdot \mathrm{min}^{-1}$ ), using aluminum capsules (typically $10 \mathrm{mg}$ of polymer). The thermograms were recorded according to the following cycles: $-40{ }^{\circ} \mathrm{C}$ to $+200{ }^{\circ} \mathrm{C}$ at $10{ }^{\circ} \mathrm{C} \cdot \mathrm{min}^{-1} ;+200{ }^{\circ} \mathrm{C}$ to $-40{ }^{\circ} \mathrm{C}$ at $10{ }^{\circ} \mathrm{C} \cdot \mathrm{min}^{-1}$.

Typical procedure for the simultaneous copolymerization of $\mathrm{EC}$ and $\mathrm{BL}, \mathrm{VL}, \mathrm{CL}$ or LLA using [(NNO)ZnEt] or $\left[\left(\mathbf{B D I}^{i P r}\right) \mathbf{Z n}\left\{\mathbf{N}\left(\mathrm{SiMe}_{3}\right)_{2}\right\}\right]$. In a typical experiment (Table 1, entry 13), EC (103 mg, 1.17 mmol, 125 equiv.) and CL (267 mg, 2.34 mmol, 250 equiv.) were added to a solution of [(NNO)ZnEt] $(4.0 \mathrm{mg}, 9.3 \mu \mathrm{mol}, 1$ equiv. $)$ in toluene $(0.1 \mathrm{~mL})$. The mixture was then stirred at $60{ }^{\circ} \mathrm{C}$ in the case of BL, VL or CL, and at $100{ }^{\circ} \mathrm{C}$ in the case of LLA, over the appropriate period of time (reaction times were not systematically optimized). The polymerization was then quenched upon addition of an acetic acid solution 
(ca. $0.05 \mathrm{~mL}$ of a $1.6 \mathrm{~mol} . \mathrm{L}^{-1}$ solution in toluene). In the case of $\mathrm{BL}$, the conversion was determined from this crude reaction mixture. In the case of VL and CL comonomers, the reaction mixture was concentrated to dryness under vacuum, and the conversion of both monomers was determined by ${ }^{1} \mathrm{H} \mathrm{NMR}$ analysis of the residue in $\mathrm{CDCl}_{3}$. The crude polymer was next dissolved in $\mathrm{CH}_{2} \mathrm{Cl}_{2}(\mathrm{ca} .2 \mathrm{~mL})$ and precipitated in cold methanol (ca. $\left.10 \mathrm{~mL}\right)$, filtered and dried under vacuum. The final P(EC-co-BL,-VL, -CL, or -LLA) copolymers were then analyzed by NMR, SEC and DSC.

Typical procedure for the simultaneous copolymerization of EC and BL, VL, CL or

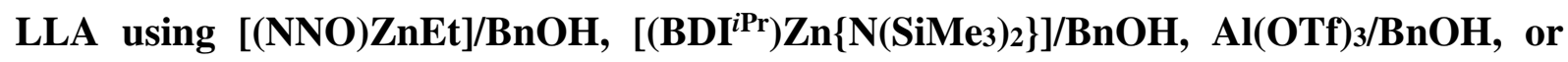
TBD. In a typical experiment (Table 1, entry 18), [(NNO)ZnEt] (5.0 mg, $11.7 \mu$ mol, 1 equiv.) was added to $\mathrm{BnOH}(1.2 \mu \mathrm{L}, 11.7 \mu \mathrm{mol}, 1$ equiv.) placed in toluene (ca. $0.1 \mathrm{~mL})$ and stirred over $15 \mathrm{~min}$ just prior to the addition of both monomers, CL (267 mg, $2.34 \mathrm{mmol}, 200$ equiv.) and EC (1.03 g, $11.7 \mathrm{mmol}, 1000$ equiv.). The remaining of the procedure was identical to that described above for the simultaneous copolymerization of EC and BL, VL, CL or LLA using only $[(\mathrm{NNO}) \mathrm{ZnEt}]$ or $\left[\left(\mathrm{BDI}^{i \mathrm{Pr}}\right) \mathrm{Zn}\left\{\mathrm{N}\left(\mathrm{SiMe}_{3}\right)_{2}\right\}\right]$.

\section{Results and Discussion}

Previous studies on the ROP of cyclic esters such as BL, LLA, cyclohexene carbonate, or trimethylene carbonate, have unveiled the catalytic efficiency, both in terms of activity and productivity, of the $\beta$-diketiminate and diaminophenolate zinc complexes, $\left[\left(\mathrm{BDI}^{\mathrm{iPr}}\right) \mathrm{Zn}\left\{\mathrm{N}\left(\mathrm{SiMe}_{3}\right)_{2}\right\}\right]$ and $[(\mathrm{NNO}) \mathrm{ZnEt}]$ respectively, as well as of metal triflates $\left(\mathrm{M}(\mathrm{OTf})_{3}\right.$ with $\left.\mathrm{M}=\mathrm{Ca}, \mathrm{Sc}, \mathrm{Zn}, \mathrm{Al}, \mathrm{Bi}\right)$ and organic bases such as TBD. ${ }^{22,57,58,59}$ These catalyst systems were, in particular, effective even in the ROP of rather reluctant-to-(co)polymerize four-membered ring lactones such as BL or benzyl $\beta$-malolactonate, ${ }^{55,56,60,61,62,63,64,65}$ and of similarly hard-to-homopolymerize five-membered ring cyclohexene carbonate. ${ }^{22} \mathrm{We}$ have 
therefore selected these systems for evaluating their performances in the simultaneous ringopening copolymerization of EC with BL, VL, CL and LLA. Taking into account the reported examples mentioned above of the successful copolymerization of EC with CL and with the closely related one carbon-smaller lactone displaying similar ROP affinity, namely VL, ${ }^{43-45}$ both CL and VL looked promising for their copolymerization with EC. Finally, given the current academic and industrial interests in lactides, LLA was also evaluated as a comonomer.

Synthesis of EC/lactones and EC/lactide random copolymers. The EC/BL, VL, CL, LLA copolymerizations were run in bulk (i.e., solvent-free reactions) at $60-110{ }^{\circ} \mathrm{C}$ using $\mathrm{Al}(\mathrm{OTf})_{3}, \quad\left[\left(\mathrm{BDI}^{i \mathrm{Pr}}\right) \mathrm{Zn}\left\{\mathrm{N}\left(\mathrm{SiMe}_{3}\right)_{2}\right\}\right],[(\mathrm{NNO}) \mathrm{ZnEt}]$ or $\mathrm{TBD}$, in the absence or presence (typical $[\text { catalyst }]_{0} /[\mathrm{BnOH}]_{0}$ ratio $=1: 1-5$; “immortal” $\mathrm{ROP}$ conditions $)^{66,67}$ of $\mathrm{BnOH}$. It is noteworthy that all these systems remain ineffective in homopolymerization of EC (typical operating conditions: toluene at $110^{\circ} \mathrm{C}$ or in bulk at $180{ }^{\circ} \mathrm{C}$ over $24-48 \mathrm{~h}$ ). The most significant results for the simultaneous copolymerizations of EC with lactones and LLA, providing PEC copolymers with poly(BL) (PBL, also referred to as poly(3-hydroxybutyrate), PHB, the most common poly(hydroxyalkanoate), poly(VL) (PVL), poly(CL) (PCL), and poly(LLA) (PLLA)) segments, are gathered in Table 1 and Table 2, respectively. 
Table 1. Simultaneous copolymerizations of EC with lactones mediated by various catalyst systems in bulk at different temperatures.

\begin{tabular}{|c|c|c|c|c|c|c|c|c|c|c|c|c|}
\hline Entry & Lactone & Catalyst & $\begin{array}{c}{[\mathrm{EC}]_{0} /[\text { Lactone }]_{0} /} \\
{[\text { Catalyst }]_{0} /} \\
{[\mathrm{BnOH}]_{0}{ }^{\mathrm{a}}}\end{array}$ & $\begin{array}{c}{[\mathrm{EC}]_{0} /} \\
{[\text { Lactone }]_{0}} \\
\text { molar ratio }\end{array}$ & $\begin{array}{l}\text { Temp. } \\
\left({ }^{\circ} \mathrm{C}\right)\end{array}$ & $\begin{array}{l}\text { Reaction } \\
\text { Time }^{\mathrm{b}} \\
\text { (h) }\end{array}$ & $\begin{array}{c}\text { EC } \\
\text { Conv. }^{c} \\
(\%)\end{array}$ & $\begin{array}{c}\text { Lactone } \\
\text { Conv. }^{c} \\
(\%)\end{array}$ & $\begin{array}{c}\text { EC } \\
\text { inserted }^{\mathrm{d}} \\
(\mathrm{mol} \%)\end{array}$ & $\begin{array}{c}M_{\mathrm{n}, \text { theo }}{ }^{\mathrm{e}} \\
\left(\mathrm{g} \cdot \mathrm{mol}^{-1}\right)\end{array}$ & $\begin{array}{c}M_{\mathrm{n}, \sec }{ }^{\mathrm{f}} \\
\left(\mathrm{g} \cdot \mathrm{mol}^{-1}\right)\end{array}$ & $\bigoplus_{M}^{g}$ \\
\hline 1 & $\mathrm{BL}$ & $\mathrm{Al}(\mathrm{OTf})_{3}$ & $200: 400: 1: 5$ & $33: 67$ & 110 & 5 & $27^{\mathrm{h}}$ & 92 & nd & 6500 & nd & nd \\
\hline 2 & BL & {$\left[\left(\mathrm{BDI}^{i \mathrm{Pr}}\right) \mathrm{Zn}\left\{\mathrm{N}\left(\mathrm{SiMe}_{3}\right)_{2}\right\}\right]$} & $165: 500: 1: 5$ & $25: 75$ & 80 & 6.25 & nd & nd & 15 & nd & 5800 & 1.24 \\
\hline 3 & $\mathrm{BL}$ & {$\left[\left(\mathrm{BDI}^{i \mathrm{Pr}}\right) \mathrm{Zn}\left\{\mathrm{N}\left(\mathrm{SiMe}_{3}\right)_{2}\right\}\right]$} & $250: 500: 1: 5$ & $33: 67$ & 90 & 3.5 & 25 & 95 & 18 & 9300 & 6000 & 1.29 \\
\hline 4 & $\mathrm{BL}$ & {$[(\mathrm{NNO}) \mathrm{ZnEt}]$} & 250:500:1:0 & $33: 67$ & 60 & 5 & 33 & 81 & 26 & 42100 & 17400 & 1.56 \\
\hline 5 & $\mathrm{BL}$ & [(NNO)ZnEt] & $250: 500: 1: 0^{\mathrm{i}}$ & $33: 67$ & 60 & 6 & 44 & 97 & 21 & 51400 & 34400 & 1.62 \\
\hline 6 & BL & {$[(\mathrm{NNO}) \mathrm{ZnEt}]$} & $250: 500: 1: 5$ & $33: 67$ & 60 & 6 & 32 & 83 & 23 & 8500 & 7500 & 1.32 \\
\hline 7 & VL & [(NNO)ZnEt] & 125:250:1:0 & $33: 67$ & 60 & 1 & 21 & 78 & 13 & 21900 & 19800 & 1.79 \\
\hline 8 & VL & {$[(\mathrm{NNO}) \mathrm{ZnEt}]$} & 250:250:1:0 & $50: 50$ & 60 & 4 & 9 & 84 & 23 & 23000 & 39780 & 1.56 \\
\hline 9 & VL & [(NNO)ZnEt] & $500: 250: 1: 0$ & $67: 33$ & 60 & 2 & 0 & 18 & 0 & 4500 & nd $^{\mathrm{j}}$ & $\mathrm{nd}^{\mathrm{j}}$ \\
\hline 10 & VL & {$[(\mathrm{NNO}) \mathrm{ZnEt}]$} & 500:250:1:0 & $67: 33$ & 60 & 7 & 0 & 15 & 0 & 3750 & $\mathrm{nd}^{\mathrm{j}}$ & $\mathrm{nd}^{\mathrm{j}}$ \\
\hline 11 & VL & {$[(\mathrm{NNO}) \mathrm{ZnEt}]$} & 250:250:1:1 & $50: 50$ & 60 & 3 & 9 & 89 & 22 & 24300 & 22100 & 1.39 \\
\hline 12 & $\mathrm{CL}$ & $\mathrm{Al}(\mathrm{OTf})_{3}$ & $250: 500: 1: 2.5$ & $33: 67$ & 110 & 15 & $100^{h}$ & 100 & nd & 37700 & nd & nd \\
\hline 13 & $\mathrm{CL}$ & {$[(\mathrm{NNO}) \mathrm{ZnEt}]$} & $125: 250: 1: 0$ & $33: 67$ & 60 & 4 & 27 & 100 & 14 & 31500 & 28700 & 1.59 \\
\hline
\end{tabular}




\begin{tabular}{|c|c|c|c|c|c|c|c|c|c|c|c|c|}
\hline 14 & $\mathrm{CL}$ & {$[(\mathrm{NNO}) \mathrm{ZnEt}]$} & 250:250:1:0 & $50: 50$ & 60 & 0.5 & 30 & 84 & 28 & 30600 & 50700 & 1.64 \\
\hline 15 & CL & {$[(\mathrm{NNO}) \mathrm{ZnEt}]$} & 500:250:1:0 & $67: 33$ & 60 & 1 & 20 & 85 & 33 & 33000 & 37500 & 1.65 \\
\hline 16 & CL & {$[(\mathrm{NNO}) \mathrm{ZnEt}]$} & 1000:250:1:1 & $80: 20$ & 60 & 1 & 10 & 66 & 37 & 27600 & 21600 & 1.45 \\
\hline 17 & CL & {$[(\mathrm{NNO}) \mathrm{ZnEt}]$} & 1000:250:1:1 & $80: 20$ & 60 & 2 & 8 & 99 & 20 & 35300 & 26200 & 1.51 \\
\hline 18 & $\mathrm{CL}$ & {$[(\mathrm{NNO}) \mathrm{ZnEt}]$} & 1000:200:1:1 & $83: 17$ & 60 & 2.25 & 9 & 99 & 33 & 30500 & $\mathrm{nd}^{\mathrm{j}}$ & $\mathrm{nd}^{\mathrm{j}}$ \\
\hline 19 & CL & {$[(\mathrm{NNO}) \mathrm{ZnEt}]$} & 2000:400:1:1 & $83: 17$ & 60 & 2.75 & 10 & 88 & 34 & 57850 & 28200 & 1.58 \\
\hline 20 & CL & {$[(\mathrm{NNO}) \mathrm{ZnEt}]$} & 2000:400:1:1 & $83: 17$ & 60 & 2 & 9 & 98 & 28 & 60600 & 34300 & 1.59 \\
\hline 21 & CL & TBD & 250:100:1:1 & $71: 29$ & 60 & 1 & 17 & 36 & 38 & 7850 & $11200^{\mathrm{k}}$ & 1.36 \\
\hline 22 & CL & TBD & 500:200:1:1 & $71: 29$ & 60 & $5 / 22$ & $7 / 10$ & $29 / 34$ & $\mathrm{nd}^{\mathrm{j}}$ & $\mathrm{nd}^{\mathrm{j}}$ & $\mathrm{nd}^{\mathrm{j}}$ & $\mathrm{nd}^{\mathrm{j}}$ \\
\hline 23 & CL & TBD & 750:300:1:1 & $71: 29$ & 60 & 2.25 & 1 & 10 & $\mathrm{nd}^{\mathrm{j}}$ & $\mathrm{nd}^{\mathrm{j}}$ & $\mathrm{nd}^{\mathrm{j}}$ & $\mathrm{nd}^{\mathrm{j}}$ \\
\hline
\end{tabular}

${ }^{a}$ All reactions were performed in bulk (solvent-free) unless otherwise stated. ${ }^{b}$ Reaction times were not systematically optimized. ${ }^{\mathrm{c}}$ Monomer conversion as determined by ${ }^{1} \mathrm{H}$ NMR spectroscopy of the crude reaction mixture (refer to Experimental Section). ${ }^{\mathrm{d}}$ Amount of EC inserted as determined from the crude reaction mixture (refer to Experimental Section). ${ }^{\text {e }}$ Theoretical molar mass calculated from the relation: $M_{\mathrm{n}, \text { theo }}=\left\{\left([\mathrm{EC}]_{0} /[\mathrm{X}]_{0}\right) \times\right.$ Conversion $\left.\mathrm{EC} \times M_{\mathrm{EC}}\right\}+\left\{\left([\mathrm{lactone}]_{0} /[\mathrm{X}]_{0}\right) \times\right.$ Conversion $\mathrm{Lactone} \times$ $\left.M_{\mathrm{Lactone}}\right\}+M_{\mathrm{BnOH}}$, with $[\mathrm{X}]_{0}=[\mathrm{BnOH}]_{0}$, or $[\mathrm{X}]_{0}=[\mathrm{Catalyst}]_{0}$ when $[\mathrm{BnOH}]_{0}=0, M_{\mathrm{EC}}=88 \mathrm{~g} \cdot \mathrm{mol}^{-1}, M_{\mathrm{BL}}=86 \mathrm{~g} \cdot \mathrm{mol}^{-1}, M_{\mathrm{VL}}=100 \mathrm{~g} \cdot \mathrm{mol}^{-1}, M_{\mathrm{CL}}=114 \mathrm{~g} \cdot \mathrm{mol}{ }^{-1}, M_{\mathrm{BnOH}}=$ 108 g.mol $^{-1}$. ${ }^{\mathrm{f}}$ Number-average molar mass value (uncorrected; refer to the Experimental section) determined by SEC in THF at $30{ }^{\circ} \mathrm{C}$ versus polystyrene standards. ${ }^{\mathrm{g}}$ Dispersity values determined by SEC in THF at $30{ }^{\circ} \mathrm{C} .{ }^{\mathrm{h}}$ Complete decarboxylation was observed by NMR analyses. ${ }^{\mathrm{i}}$ Reaction ran in toluene at $[\text { EC }]_{0}=4.0 \mathrm{M} .{ }^{\mathrm{j}}$ Not determined because the polymer could not be precipitated. ${ }^{\mathrm{k}} M_{\mathrm{n}}$ value determined by NMR analysis $=16400 \mathrm{~g} \cdot \mathrm{mol}^{-1}$. 
The EC/BL and EC/CL simultaneous copolymerizations were first attempted with the robust $\mathrm{Al}(\mathrm{OTf})_{3} / \mathrm{BnOH}$ system, known to withstand high temperatures in related carbonate polymerizations, ${ }^{68,69,74,75}$ at $110^{\circ} \mathrm{C}$ (Table 1 , entries 1,12 , respectively). In these copolymerizations, the lactone was (nearly) completely consumed while EC was converted to some extent (27-100\%). However, complete decarboxylation was observed, as evidenced by the absence of the typical carbonate signal in the ${ }^{13} \mathrm{C}$ NMR spectra $\left(\delta_{13 \mathrm{C}} 155.4-155.0 \mathrm{ppm}\right.$, vide infra $)^{23,45}$ of the isolated copolymers. Also, the characteristic methylene resonances of ethylenoxy units were unambiguously identified at $\delta_{1 \mathrm{H}} 3.7-3.3 \mathrm{ppm}$ and $\delta_{13 \mathrm{C}} 71.1-68.3 \mathrm{ppm}$, in agreement with literature data. ${ }^{45,70,71,72}$ This is exemplified with the spectra recorded on a sample recovered from EC/CL copolymerization (Figures S3-S4). Based on these initial results, no such EC/comonomer copolymerization using $\mathrm{Al}(\mathrm{OTf})_{3}$ was further investigated. Alternatively, catalytic systems operating under milder conditions, and ideally without concomitant decarboxylation, were then sought.

Under similar bulk conditions, yet at a lower temperature $\left(60-90{ }^{\circ} \mathrm{C}\right)$, the zinc complexes $\left[\left(\mathrm{BDI}^{i \mathrm{Pr}}\right) \mathrm{Zn}\left\{\mathrm{N}\left(\mathrm{SiMe}_{3}\right)_{2}\right\}\right]$ and $[(\mathrm{NNO}) \mathrm{ZnEt}]$, with or without $\mathrm{BnOH}$, were then evaluated (Table 1, entries 2-6, 7-11, 13-20, respectively). These copolymerizations proceeded without noticeable decarboxylation of EC. This can be ascribed to the nature of the catalyst itself but also likely as well to the relatively lower operating temperature that such systems allow. The zinc $\beta$-diketiminate complex associated to $\mathrm{BnOH}$ catalyzed the simultaneous copolymerization of EC with BL, affording 15-18 mol\% of EC inserted into the final P(EC-co-BL) copolymer (Table 1, entries 2-3). Since our previous studies on the homopolymerization of the related $5 \mathrm{CC}$ cyclohexene carbonate have shown that this zinc $\beta$-diketiminate-based catalyst is slightly less active than that based on the zinc diaminophenolate one ${ }^{22}$ further efforts were focused on the latter [(NNO)ZnEt] system. In the 
presence or in the absence of $\mathrm{BnOH},[(\mathrm{NNO}) \mathrm{ZnEt}]$ revealed indeed active in the simultaneous copolymerization of EC with lactones at a more moderate temperature of $60{ }^{\circ} \mathrm{C}$ (Table 1 , entries 4-11,13-20).

In the case of $\mathrm{BL}$ comonomer, greater $\mathrm{EC}$ insertion rates within the $\mathrm{PHB}$ were measured from $[(\mathrm{NNO}) \mathrm{ZnEt}] \quad(21-26$ mol\% $)$ as compared to $\mathrm{Al}(\mathrm{OTf})_{3}$ or $\left[\left(\mathrm{BDI}^{\mathrm{Pr}}\right) \mathrm{Zn}\left\{\mathrm{N}\left(\mathrm{SiMe}_{3}\right)_{2}\right\}\right](<18 \mathrm{~mol} \%)$. Whether exogenous alcohol was involved or not, the simultaneous copolymerization of EC with VL or CL using [(NNO)ZnEt] proceeded also at $60{ }^{\circ} \mathrm{C}$, generally within relatively short reaction times; these conditions compare favorably to those reported for the alike EC/VL and EC/CL copolymerizations mediated by samarium/neodymium-based systems (reaction times typically in the range 18-72 $\mathrm{h}$ for copolymerizations ran at $\left.20-25^{\circ} \mathrm{C}\right) .{ }^{23,45,46}$ Copolymers containing a significant amount (13-38 mol\%) of EC units were thus recovered (Table 1, entries 7-20). The presence of $\mathrm{BnOH}$ does not seem to improve the behavior of $[(\mathrm{NNO}) \mathrm{ZnEt}]$ in the EC/VL and EC/CL copolymerization (compare entries $8 \mathrm{vs}$. 11). The EC conversion rates remain limited to $c a$. 22-200 equiv (vs. Zn), regardless of the reaction time and of the $[\mathrm{EC}]_{0} /[\mathrm{VL} / \mathrm{CL}]_{0}$ ratio (Table 1, entries 7-11 and 13-20). At $[\mathrm{EC}]_{0} /[\mathrm{CL}]_{0}=80: 20$, up to $37 \mathrm{~mol} \%$ of $\mathrm{EC}$ are inserted in the final copolymer within $1 \mathrm{~h}$, with $10 \%$ and $66 \%$ of EC and CL conversion, respectively (Table 1, entry 16). This incorporation rate of $37 \mathrm{~mol} \% \mathrm{EC}$ within the final $\mathrm{P}(\mathrm{EC}-\mathrm{co}-\mathrm{CL})$ copolymer represents the optimized value under such polymerization conditions. Although doubling the polymerization time promoted the CL consumption, the EC conversion did not similarly increase, thereby resulting in an EC incorporation rate lowered to $20 \mathrm{~mol} \%$ (Table 1, entries 16-17). These observations suggest that EC was most likely inserted at the earlier stage of the EC/CL copolymerization. In comparison, the EC/VL copolymerization did not allow as much EC and VL consumption (Table 1, entries 7-9 vs. 13-15). The catalytic activity and the eventual insertion of EC into PVL appears to be quite dependent on the initial loading of EC: 
the higher the EC content in the initial mixture of the two comonomers, the lower the overall catalytic activity (i.e., the lower the conversion of both VL and EC), and eventually the more difficult the EC insertion. Overall, the [(NNO)ZnEt] catalytic system allows to insert up to 23 mol\% and 33-37 mol\% of EC in the VL and CL copolymer, respectively. These contents are unmatched as, so far, the maximum EC incorporated into a PVL and PCL backbone was reported at $10 \mathrm{~mol} \%$ and $31 \mathrm{~mol} \%$, respectively, from $\left[\left(\mathrm{C}_{5} \mathrm{Me}_{5}\right)_{2} \mathrm{SmMe}(\mathrm{THF})\right]$ (with $[\mathrm{EC}]_{0} /[\mathrm{VL}]_{0}=50: 50$ and $[\mathrm{EC}]_{0} /[\mathrm{CL}]_{0}=60: 40$ in $72 \mathrm{~h}$ at $\left.25^{\circ} \mathrm{C}\right) .{ }^{44}$ Also, the present $[(\mathrm{NNO}) \mathrm{ZnEt}] / \mathrm{BnOH}$ catalytic system enables effective EC/VL and EC/CL copolymerizations, without decarboxylation, with $[\mathrm{EC}]_{0} /[\mathrm{VL}]_{0}$ and $[\mathrm{EC}]_{0} /[\mathrm{CL}]_{0}$ ratios still operative up to 50:50 and 83:17, respectively. These initial loadings of comonomers allowing copolymerization compare favorably with the 50:50 and 60:40 ones, respectively, previously optimized for the $\mathrm{Sm}^{\mathrm{III}}$ methyl metallocene, as in the latter case, decarboxylation was observed at $[\mathrm{EC}]_{0} /[\mathrm{VL}]_{0}=60: 40$ and $[\mathrm{EC}]_{0} /[\mathrm{CL}]_{0}=70: 30 .{ }^{44}$

Organocatalysts, known as active in the ROP of cyclic carbonates, ${ }^{22,39,57,59,73,74,75}$ were also examined in the copolymerization of EC with CL, selected as model comonomer (Table 1, entries 21-23). TBD combined to $\mathrm{BnOH}$ was found active, yet to a lesser extent than the [(NNO)ZnEt]/BnOH catalytic system. Only $17 \mathrm{~mol} \%$ and $36 \mathrm{~mol} \%$ of $\mathrm{EC}$ and CL, respectively, were consumed within $1 \mathrm{~h}$ at $60{ }^{\circ} \mathrm{C}$ (vs. $20 \mathrm{~mol} \%$ and $85 \mathrm{~mol} \%$, respectively, with the zinc system; Table 1, entries 21,15). The amount of EC ultimately inserted in the copolymer produced with TBD was as high as $38 \mathrm{~mol} \%$, thus supporting the consumption of EC at the earlier stage of the polymerization, as observed above with the diaminophenolate zinc system. A similar behavior has been reported for the copolymerization of CL with $\gamma$-butyrolactone, a monomer similarly known to be non-easily polymerizable. ${ }^{76}$ Further attempts with various $[\mathrm{EC}]_{0} /[\mathrm{CL}]_{0}$ and extended reactions time did not reveal more successful, and TBD was thus not further considered. 
Incorporation of carbonate units such as ECs along the poly(lactide) backbone to improve its physical properties is also one of our current topical endeavor. ${ }^{57,58,59}$ To our knowledge, the sole EC/LLA copolymerization reported prior to this work was carried out from $\mathrm{SmI}_{2} / \mathrm{Sm}$, and ultimately afforded at best $4 \mathrm{~mol} \%$ of EC randomly inserted into the PLLA chain. ${ }^{45}$ Investigations of the simultaneous EC/LLA copolymerization performed at $60-150{ }^{\circ} \mathrm{C}$ with [(NNO)ZnEt] without $\mathrm{BnOH}$, revealed similarly successful (Table 2, entries 1-15). The reaction temperature significantly influenced the EC content into the recovered copolymer. Raising the temperature from $60{ }^{\circ} \mathrm{C}$ to $100{ }^{\circ} \mathrm{C}$ improved the $\mathrm{EC}$ insertion rate from 2 to $7 \mathrm{~mol} \%$ (Table 2, entries 2,5). Similarly, at a [EC $]_{0} /[\mathrm{LLA}]_{0}$ ratio of 83:17, the EC content was improved from 3 to 14 mol\% by increasing the temperature from $60{ }^{\circ} \mathrm{C}$ to $120{ }^{\circ} \mathrm{C}$ (Table 2, entries 7,11). However, higher temperature significantly affected the control of the copolymerization by promoting undesirable transesterification/transcarbonatation and/or chain transfer reactions, resulting in the lowering of the copolymer molar mass values. The copolymer prepared at $150{ }^{\circ} \mathrm{C}$ similarly consisted of oligomers which could not be precipitated from $\mathrm{CH}_{2} \mathrm{Cl}_{2} / \mathrm{MeOH}$ (Table 2, entry 15 ). At $100^{\circ} \mathrm{C}$, increasing the $[\mathrm{EC}]_{0} /[\mathrm{LLA}]_{0}$ ratio from 17:83 to 83:17 resulted as expected in a larger insertion of EC units within PLLA, ranging from 1.5 to $17 \mathrm{~mol} \%$, respectively (Table 2, entries 3-6,10). The EC/LLA simultaneous copolymerization carried out at $100{ }^{\circ} \mathrm{C}$ using $\left[\left(\mathrm{BDI}^{i \mathrm{Pr}}\right) \mathrm{Zn}\left\{\mathrm{N}\left(\mathrm{SiMe}_{3}\right)_{2}\right\}\right]$ afforded high LLA conversions, but the extent of EC inserted into PLLA remained low (5 mol\%; Table 2, entries 16-17). 
Table 2. Simultaneous copolymerization of EC with LLA mediated by zinc-based catalyst systems in bulk at different temperatures.

\begin{tabular}{|c|c|c|c|c|c|c|c|c|c|c|c|}
\hline Entry & Complex & $\begin{array}{c}{[\mathrm{EC}]_{0} /[\mathrm{LLA}]_{0} /} \\
{[\text { Catalyst }]_{0} /} \\
{[\mathrm{BnOH}]_{0}{ }^{\mathrm{a}}}\end{array}$ & $\begin{array}{c}{[\mathrm{EC}]_{0} /[\mathrm{LLA}]_{0}} \\
\text { molar ratio }\end{array}$ & $\begin{array}{l}\text { Temp. } \\
\left({ }^{\circ} \mathrm{C}\right)\end{array}$ & $\begin{array}{c}\text { Reaction } \\
\text { Time }^{b} \\
\text { (h) }\end{array}$ & $\begin{array}{c}\text { EC } \\
\text { Conv. }{ }^{c} \\
(\%)\end{array}$ & $\begin{array}{c}\text { LLA } \\
\text { Conv. }{ }^{c} \\
(\%)\end{array}$ & $\begin{array}{c}\text { EC inserted }{ }^{\mathrm{d}} \\
(\mathrm{mol} \%)\end{array}$ & $\begin{array}{l}M_{\mathrm{n}, \text { theo }}{ }^{\mathrm{e}} \\
\left(\mathrm{g} \cdot \mathrm{mol}^{-1}\right)\end{array}$ & $\begin{array}{c}M_{\mathrm{n}, \mathrm{sec}}{ }^{\mathrm{f}} \\
\left(\mathrm{g} \cdot \mathrm{mol}^{-1}\right)\end{array}$ & $\bigoplus_{M}{ }^{g}$ \\
\hline 1 & $(\mathrm{NNO}) \mathrm{ZnEt}$ & 160:160:1:0 & $50: 50$ & 60 & 0.5 & 4 & 95 & 2 & 22400 & nd & nd \\
\hline 2 & $(\mathrm{NNO}) \mathrm{ZnEt}$ & 100:500:1:0 & $17: 83$ & 100 & 0.5 & nd & nd & 1.5 & nd & 96300 & 2.16 \\
\hline 3 & $(\mathrm{NNO}) \mathrm{ZnEt}$ & 100:500:1:0 & $17: 83$ & 100 & 0.5 & nd & nd & 4 & nd & 56900 & 2.15 \\
\hline 4 & $(\mathrm{NNO}) \mathrm{ZnEt}$ & 150:150:1:0 & $50: 50$ & 100 & 0.2 & 6 & 94 & 7 & 21100 & 37700 & 1.39 \\
\hline 5 & $(\mathrm{NNO}) \mathrm{ZnEt}$ & 250:100:1:0 & $71: 29$ & 100 & 0.5 & 6 & 96 & 9 & 15100 & 18600 & 1.60 \\
\hline 6 & $(\mathrm{NNO}) \mathrm{ZnEt}$ & 500:100:1:0 & $83: 17$ & 60 & 1 & 1 & 85 & 3 & 12700 & 78100 & 1.85 \\
\hline 7 & $(\mathrm{NNO}) \mathrm{ZnEt}$ & 500:100:1:0 & $83: 17$ & 80 & 1.5 & 3 & 94 & 13 & 14900 & 48300 & 1.59 \\
\hline 8 & $(\mathrm{NNO}) \mathrm{ZnEt}$ & 500:100:1:0 & $83: 17$ & 100 & 2.5 & 7 & 90 & 17 & 16000 & 29500 & 1.73 \\
\hline 9 & $(\mathrm{NNO}) \mathrm{ZnEt}$ & 500:100:1:0 & $83: 17$ & 120 & 1 & 4 & 90 & 14 & 14700 & 19400 & 1.50 \\
\hline 10 & $(\mathrm{NNO}) \mathrm{ZnEt}$ & 500:100:1:0 & $83: 17$ & 150 & 3 & 3 & 83 & $\mathrm{nd}^{h}$ & 13300 & $\mathrm{nd}^{h}$ & nd $^{h}$ \\
\hline 11 & $(\mathrm{NNO}) \mathrm{ZnEt}$ & 500:100:1:0 & $83: 17$ & 150 & 1 & 2 & 80 & $\mathrm{nd}^{h}$ & 12400 & $\mathrm{nd}^{h}$ & nd $^{h}$ \\
\hline
\end{tabular}




\begin{tabular}{|c|c|c|c|c|c|c|c|c|c|c|c|}
\hline 12 & (NNO)ZnEt & 2500:500:1:0 & $83: 17$ & 100 & 3 & 4 & 90 & 11 & 73600 & 60200 & 1.74 \\
\hline 13 & (NNO)ZnEt & 500:100:1:5 & $83: 17$ & 100 & 1 & 7 & 92 & $\mathrm{nd}^{h}$ & 3300 & $\mathrm{nd}^{h}$ & nd $^{h}$ \\
\hline 14 & $(\mathrm{BDI}) \mathrm{Zn}\left[\mathrm{N}(\mathrm{TMS})_{2}\right]$ & 500:100:1:0 & $83: 17$ & 100 & 0.5 & 2 & 90 & 5 & 13840 & 44300 & 1.74 \\
\hline 15 & $(\mathrm{BDI}) \mathrm{Zn}\left[\mathrm{N}(\mathrm{TMS})_{2}\right]$ & 500:100:1:0 & $83: 17$ & 100 & 0.5 & 1 & 83 & 5 & 12400 & 41200 & 1.69 \\
\hline
\end{tabular}

${ }^{a}$ All reactions were performed in bulk (solvent-free) unless otherwise stated. ${ }^{\mathrm{b}}$ Reaction times were not systematically optimized. ${ }^{\mathrm{c}}$ Monomer conversion as determined by ${ }^{1} \mathrm{H}$ NMR spectroscopy of the crude reaction mixture (refer to Experimental Section). ${ }^{\mathrm{d}}$ Amount of EC inserted as determined from the crude reaction mixture (refer to experimental section). ${ }^{\text {e }}$ Theoretical molar mass calculated from the relation: $M_{\mathrm{n}, \text { theo }}=$ $\left\{\left([\mathrm{EC}]_{0} /[\mathrm{X}]_{0}\right) \times\right.$ Conversion $\left._{\mathrm{EC}} \times M_{\mathrm{EC}}\right\}+\left\{\left([\mathrm{LLA}]_{0} /[\mathrm{X}]_{0}\right) \times\right.$ Conversion $\left._{\mathrm{LLA}} \times M_{\mathrm{LLA}}\right\}+M_{\mathrm{BnOH}}$, with X $=[\mathrm{BnOH}]_{0}$ or X $=[\mathrm{Catalyst}]_{0}$ when $[\mathrm{BnOH}]_{0}=0$, $M_{\mathrm{EC}}=88 \mathrm{~g} \cdot \mathrm{mol}^{-1}, M_{\mathrm{LLA}}=144 \mathrm{~g} \cdot \mathrm{mol}^{-1}, M_{\mathrm{BnOH}}=108 \mathrm{~g} \cdot \mathrm{mol}^{-1} .{ }^{\mathrm{f}}$ Number-average molar mass value (uncorrected; refer to the Experimental section) determined by SEC in THF at $30{ }^{\circ} \mathrm{C}$ versus polystyrene standards. ${ }^{\mathrm{g}}$ Dispersity values determined by SEC in THF at $30{ }^{\circ} \mathrm{C}$. ${ }^{\mathrm{h}} \mathrm{Not}$ determined because the polymer could not be precipitated. 
Characterization of EC/lactones and EC/lactide random copolymers. All these EC lactones/lactide copolymerizations afforded copolymers with molar mass values determined by SEC $\left(M_{\mathrm{nSEC}}\right.$; values uncorrected for the possible difference in the hydrodynamic volume of the copolymers $v s$. polystyrene standards used for calibration) varying from 6000 to 96350 g.mol ${ }^{-1}$, and dispersity values generally lower than $\bigoplus_{M}=1.85$. Although the molar mass values of these EC/lactones and EC/lactide random copolymers measured by SEC did not always matched with the theoretical data based on the conversion of both conomomers, ${ }^{77}$ these data suggested fairly controlled copolymerizations with yet some undesirable side reactions (typical inter- and intra-molecular - reshuffling and backbiting transesterification/transcarbonatation and/or chain transfer reactions). The dispersity values measured in the present study for EC/VL and EC/CL copolymers $\left(\bigoplus_{M}=1.36-1.79\right)$, were however somewhat lower than those reported in the literature for these same copolymers $\left(\nexists_{M}\right.$ $=c a \cdot 1.52-2.12) \cdot{ }^{43-46}$ On the other hand, the EC/LLA copolymers herein synthesized displayed slightly larger dispersity values $\left(\bigoplus_{M}=1.50-2.16\right)$ as compared to those measured on alike copolymers prepared from $\mathrm{SmI}_{2} / \mathrm{Sm}\left(\bigoplus_{\mathrm{M}}=1.30-1.67\right)$ from yet lower $\mathrm{EC}$ initial loadings $\left([\mathrm{EC}]_{0}:[\mathrm{LLA}]_{0}=25: 75\right.$ to $\left.62: 38\right) .{ }^{45}$

The EC copolymers were characterized by ${ }^{1} \mathrm{H}$ and ${ }^{13} \mathrm{C}$ NMR spectroscopy and DSC analysis. Structural identification was based on the detailed $\left({ }^{1} \mathrm{H},{ }^{13} \mathrm{C}\left\{{ }^{1} \mathrm{H}\right\},{ }^{1} \mathrm{H}_{-}{ }^{13} \mathrm{C}\right.$ HMQC and HMBC NMR spectroscopy) characterization of EC/CL copolymers (Figures S3-S9, 1-9, respectively), as reported by Agarwal et al. ${ }^{45}$ and Evans et $a l .{ }^{43}$ The integrals of the EC/lactone or lactide NMR signals indeed matched the conversion of each monomer, respectively.

$P\left(E C\right.$-co-CL) copolymers. The typical ${ }^{1} \mathrm{H}$ NMR spectrum of a $\mathrm{P}(\mathrm{EC}-\mathrm{co}-\mathrm{CL})$ prepared by $\mathrm{Zn}$ catalysis displays the characteristic signals of both PCL $\left(\delta 4.04,-\mathrm{OCH}_{2} \mathrm{CH}_{2}-; 2.30\right.$, $\left.-\mathrm{C}(\mathrm{O}) \mathrm{CH}_{2} \mathrm{CH}_{2}-; 1.65,-\mathrm{C}(\mathrm{O}) \mathrm{CH}_{2} \mathrm{CH}_{2}-,-\mathrm{OCH}_{2} \mathrm{CH}_{2}-; 1.39 \mathrm{ppm},-\mathrm{CH}_{2} \mathrm{CH}_{2} \mathrm{CH}_{2}\right)$ and PEC $(\delta$ 
4.26-4.35, $-\mathrm{C}(\mathrm{O}) \mathrm{OCH}_{2}-,-\mathrm{OCH}_{2} \mathrm{CH}_{2}-$ ) (Figure 1). As mentioned above, the absence of the signals of ether units $\left(\delta_{1 \mathrm{H}} c a .3 .7-3.3 \mathrm{ppm} \text { and } \delta_{13 \mathrm{C}} c a .71 .1-68.3 \mathrm{ppm}\right)^{45,70-72}$ indicated the absence of concomitant decarboxylation during the copolymerization. The PCL resonances of $\mathrm{P}(\mathrm{EC}-\mathrm{co}-\mathrm{CL})$ samples were split into a set of two distinct signals assigned to two types of CL chemical environments in the copolymer (i.e., $\mathrm{CL}-C L-\mathrm{CL}$ and $\mathrm{EC}-C L-\mathrm{CL}$ ) as previously reported. ${ }^{43}$

As illustrated in Figure 2, the ${ }^{13} \mathrm{C}$ NMR spectra of the $\mathrm{P}(\mathrm{EC}-\mathrm{co}-\mathrm{CL})$ samples synthesized from [(NNO)ZnEt] distinctively exhibited the PCL characteristic set of signals (at $\delta 173.7,64.2,34.3,28.3,25.5$, and $24.5 \mathrm{ppm})$. Some additional resonances were clearly observed as compared to the spectrum of the alike copolymer prepared from $\mathrm{SmI}_{2} / \mathrm{Sm},{ }^{45}$ thus suggesting a distinct microstructure in the copolymer synthesized in the present study. The carbonyl region of the ${ }^{13} \mathrm{C}\left\{{ }^{1} \mathrm{H}\right\}$ NMR spectrum shows three resonances assigned to EC units inserted into the polyester within three distinct chemical environments (Figure 3). The most downfield carbonyl signal ( $\delta 155.40 \mathrm{ppm})$ may be assigned to an isolated EC unit within several consecutive CL units. Of the two other most upfield signals ( $\delta 155.06,155.11 \mathrm{ppm})$, one may correspond to two adjacent EC units or to two close by EC units separated by only one CL unit. So far, only isolated EC units giving a unique signal in the carbonyl region $(\delta c a$. $155 \mathrm{ppm})$ have been claimed for $\mathrm{P}(\mathrm{EC}-\mathrm{co}-\mathrm{CL})$ in the literature. ${ }^{43,45}$ Agarwal et al. reported that the absence of several signals assigned to the carbonyl of EC suggested its occurrence as isolated EC units. Furthermore, the absence in the present copolymer spectrum of three (or more) consecutive EC units was suggested by the absence of signal at $\delta 154.69 \mathrm{ppm}$, as recorded in the spectrum of a PEC homopolymer (Figure S2; prepared from $\mathrm{CO}_{2} /$ ethylene oxide copolymerization) (Figures 2, S6). The assignment of the signal at $\delta 155.11 \mathrm{ppm}$ to two adjacent EC units or to two close by EC units separated by only one CL unit, was suggested by the relative intensity of the signals at $\delta 155.40,155.11$ and $155.06 \mathrm{ppm}$ according to the 
amount of EC inserted within the polyester: the larger the insertion of EC (i.e., the more likely two EC units are to be next to each other), the larger the intensity of the signal at $\delta 155.11$ ppm vs. that at $\delta 155.40 \mathrm{ppm}$ (Figure 3). The carbonyl signal at $\delta 155.06 \mathrm{ppm}$ may be assigned to a EC unit in a slightly different environment or, taking into account its small intensity ${ }^{78}$ to a chain-end EC-containing unit; this could not be clarified yet.
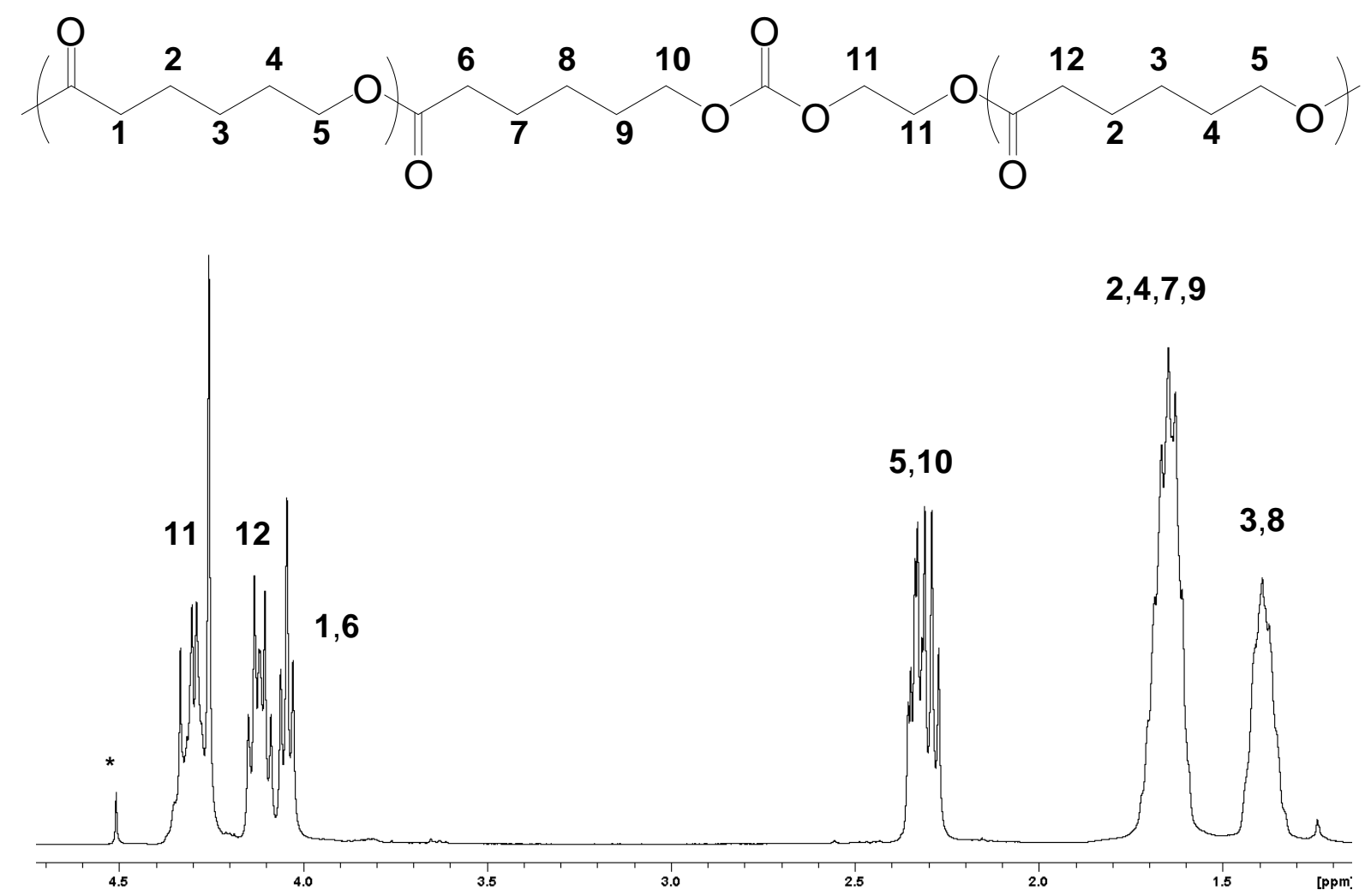

Figure 1. ${ }^{1} \mathrm{H}$ NMR spectrum $\left(400 \mathrm{MHz}, \mathrm{CDCl}_{3}, 23{ }^{\circ} \mathrm{C}\right)$ of a $\mathrm{P}(\mathrm{EC}-\mathrm{co}-\mathrm{CL})$ synthesized from [(NNO)ZnEt] and featuring $33 \mathrm{~mol} \%$ of inserted EC (Table 1, entry 15) (* stands for residual EC). 

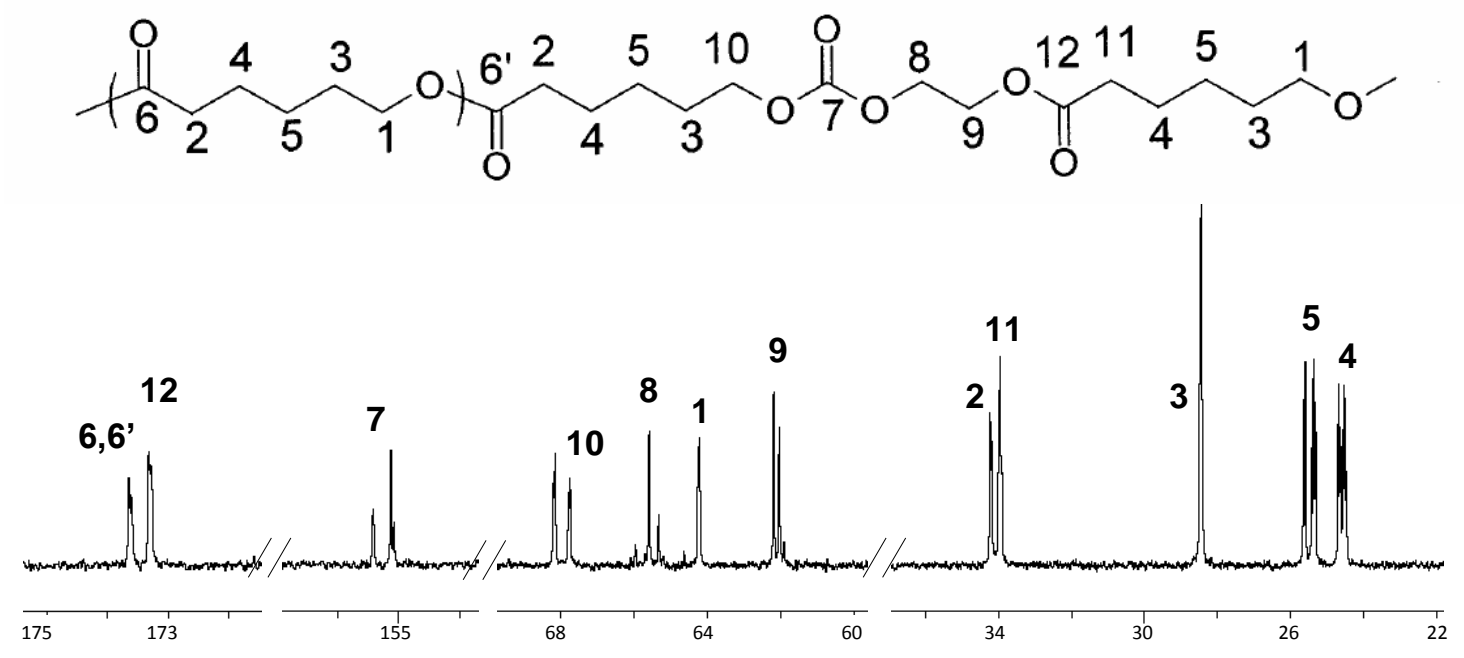

Figure 2. Details of the ${ }^{13} \mathrm{C}\left\{{ }^{1} \mathrm{H}\right\} \mathrm{NMR}$ spectrum $\left(100 \mathrm{MHz}, \mathrm{CDCl}_{3}, 23{ }^{\circ} \mathrm{C}\right)$ of a $\mathrm{P}(\mathrm{EC}-\mathrm{co}-\mathrm{CL})$ synthesized from [(NNO)ZnEt] and featuring $33 \mathrm{~mol} \%$ of inserted EC (Table 1, entry 15) and proposed assignments.

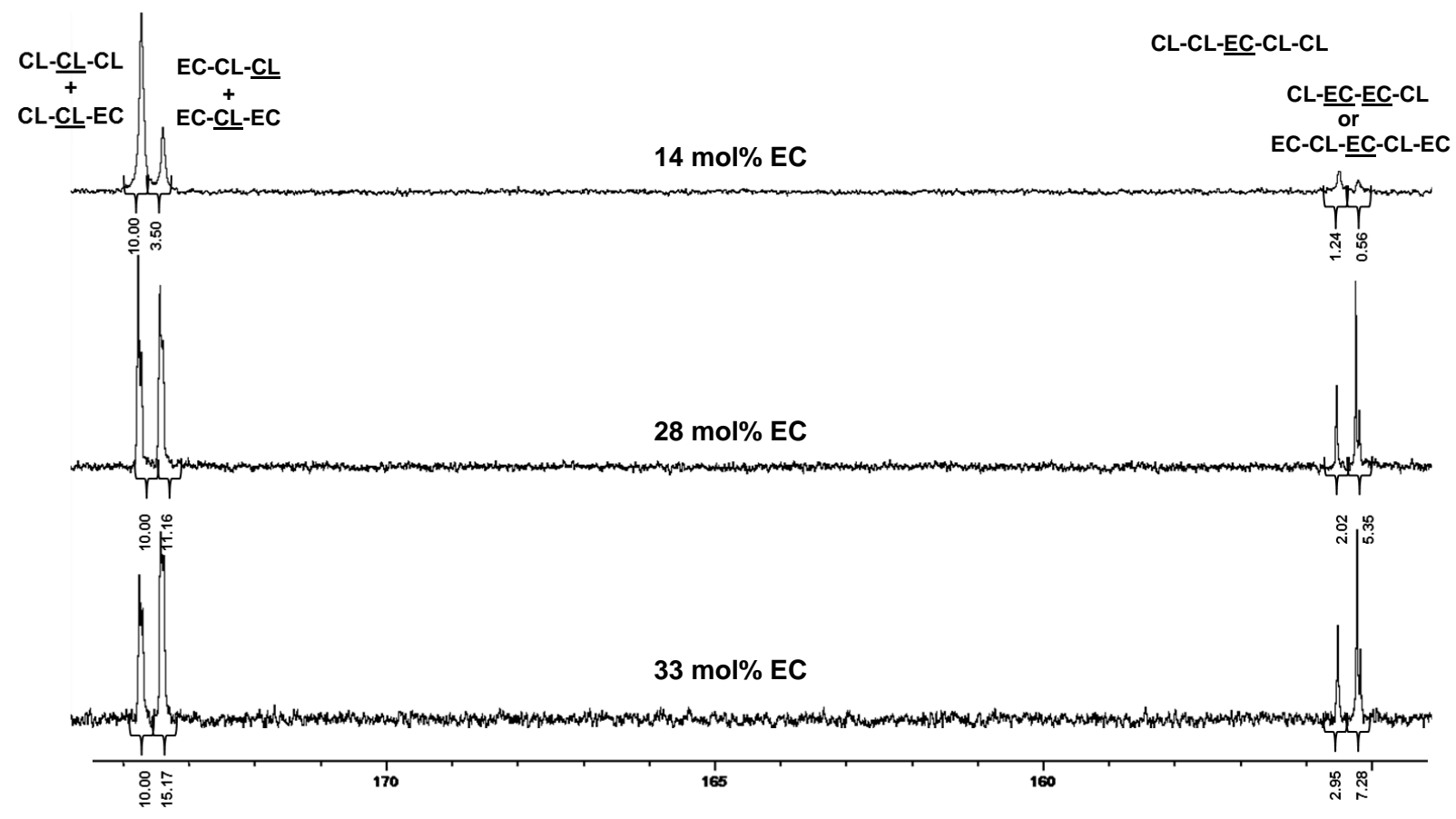

Figure 3. Carbonyl region of the ${ }^{13} \mathrm{C}\left\{{ }^{1} \mathrm{H}\right\}$ NMR spectra $\left(100 \mathrm{MHz}, \mathrm{CDCl}_{3}, 23{ }^{\circ} \mathrm{C}\right)$ of $\mathrm{P}(\mathrm{EC}-$ co-CL) samples synthesized from [(NNO)ZnEt] and featuring $14 \mathrm{~mol} \%$ (top trace), $28 \mathrm{~mol} \%$ (middle trace), or $33 \mathrm{~mol} \%$ (bottom trace) of inserted EC (Table 1, entries 13,14,15, respectively). 
$P\left(E C\right.$-co-BL) copolymers. ${ }^{1} \mathrm{H}$ NMR analysis of $\mathrm{P}(\mathrm{EC}-\mathrm{co}-\mathrm{BL})$ copolymers prepared from [(NNO)ZnEt] displayed the same signals for 3-hydroxybutyrate units as those observed in regular PHB $\left(\delta\right.$ 5.22, $\mathrm{CH}_{2} \mathrm{CH}\left(\mathrm{CH}_{3}\right) \mathrm{O} ; 2.40, \mathrm{CH}_{2} \mathrm{CH}\left(\mathrm{CH}_{3}\right) \mathrm{O} ; 1.25 \mathrm{ppm}, \mathrm{CH}_{2} \mathrm{CH}\left(\mathrm{CH}_{3}\right) \mathrm{O}$; Figure 4). Besides, another set of distinctly shifted methine, methylene and methyl hydrogens resonances assigned to BL units adjacent to EC units was observed. The ${ }^{13} \mathrm{C}\left\{{ }^{1} \mathrm{H}\right\}$ NMR spectrum proved more complicated and was not investigated in details (Figure S5).

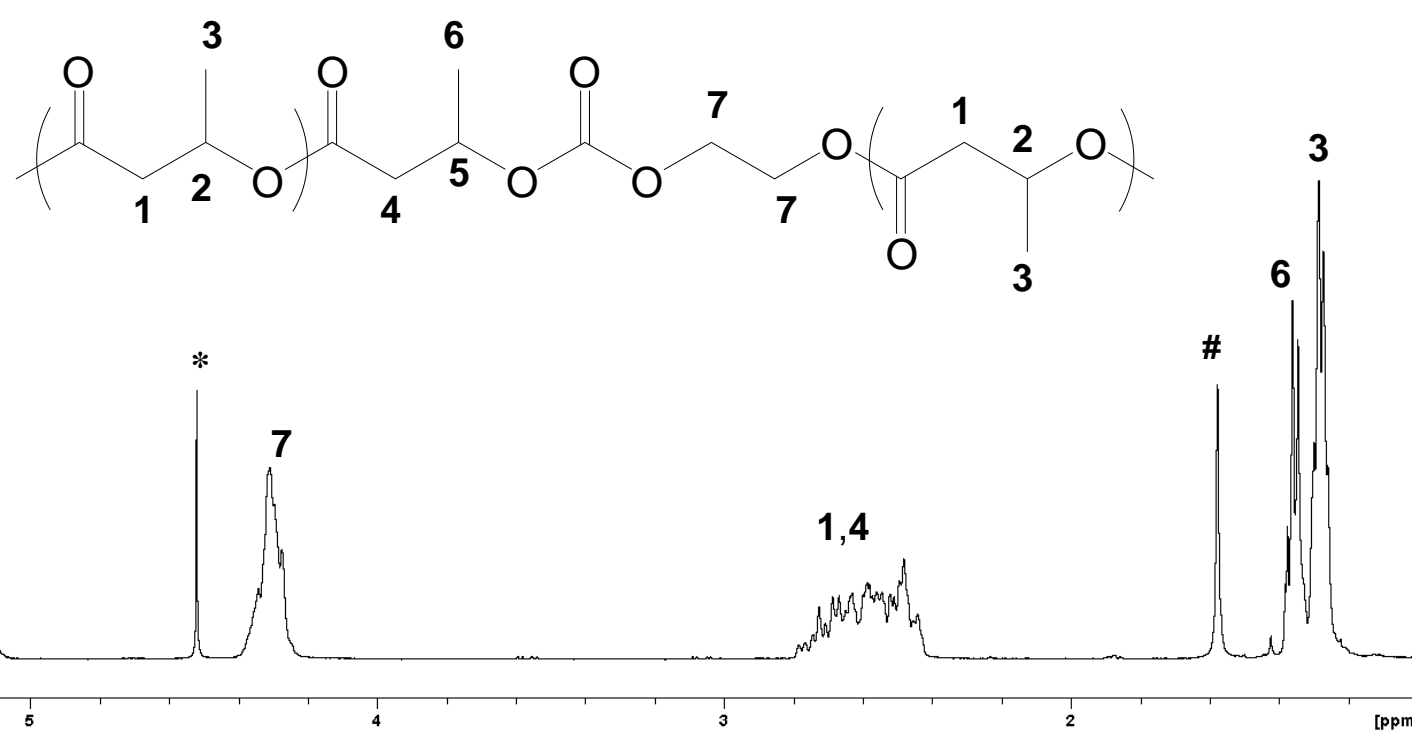

Figure 4. ${ }^{1} \mathrm{H}$ NMR spectrum $\left(400 \mathrm{MHz}, \mathrm{CDCl}_{3}, 23{ }^{\circ} \mathrm{C}\right)$ of a $\mathrm{P}(\mathrm{EC}-\mathrm{co}-\mathrm{BL})$ synthesized from [(NNO)ZnEt] and featuring $26 \mathrm{~mol} \%$ of inserted EC (Table 1, entry 4) (* and \# stand for residual $\mathrm{EC}$ and $\mathrm{H}_{2} \mathrm{O}$, respectively) and proposed assignments.

$P\left(E C\right.$-co-VL) copolymers. The ${ }^{1} \mathrm{H}$ NMR spectra of $\mathrm{P}(\mathrm{EC}-\mathrm{co}-\mathrm{VL})$ samples (Figure 5) showed the three typical resonances of the VL units $\left(\delta 4.08,-\mathrm{C}(\mathrm{O}) \mathrm{CH}_{2} \mathrm{CH}_{2}-; 2.35\right.$, $\left.-\mathrm{OCH}_{2} \mathrm{CH}_{2}-; 1.65 \mathrm{ppm},-\mathrm{C}(\mathrm{O}) \mathrm{CH}_{2} \mathrm{CH}_{2} \mathrm{CH}_{2} \mathrm{CH}_{2}\right)$. Distinct downfield shoulders were clearly observed, which were assigned to the methylene in $\alpha$-position to the $\mathrm{VL}$, and to EC-VL-VL and EC-VL-EC junctions, respectively. ${ }^{79}$ The corresponding ${ }^{13} \mathrm{C}\left\{{ }^{1} \mathrm{H}\right\}$ NMR spectra of the 
$\mathrm{P}(\mathrm{EC}-\mathrm{co}$-VL) copolymers revealed, both in the carbonyl and in the aliphatic carbon regions, several resonances for EC units inserted into the polyester (Figure 6; note that EC was deliberately added to differentiate the signals of the copolymers from that of EC). Based on the prior examination of $\mathrm{P}(\mathrm{EC}-\mathrm{co}-\mathrm{CL})$ spectra, a general assignment was proposed as depicted in Figure 6 for a copolymer containing 13 mol\% of EC. The most intense and upfield signal in the carbonate region at $\delta 155.04 \mathrm{ppm}$ is proposed to correspond to EC units surrounded by VL units on both sides (i.e. VL-EC-VL). The most downfield, low intensity signal at $\delta 155.34 \mathrm{ppm}$ may be assigned to a EC unit away by one VL unit from another EC unit (e.g. $E C-\mathrm{VL}-E C)$, or to two consecutive $\mathrm{EC}$ units adjacent to a $\mathrm{VL}$ unit (e.g. $E C-E C-\mathrm{VL})$; however, a clear cut between those two possibilities was not possible. Similarly, in the carbonyl region ( $\delta \mathrm{ca} .173 \mathrm{ppm}$ ), besides the most intense resonance assigned to PVL sequences, low intensity upfield signals are observed, reflecting VL units in close vicinity to EC units.

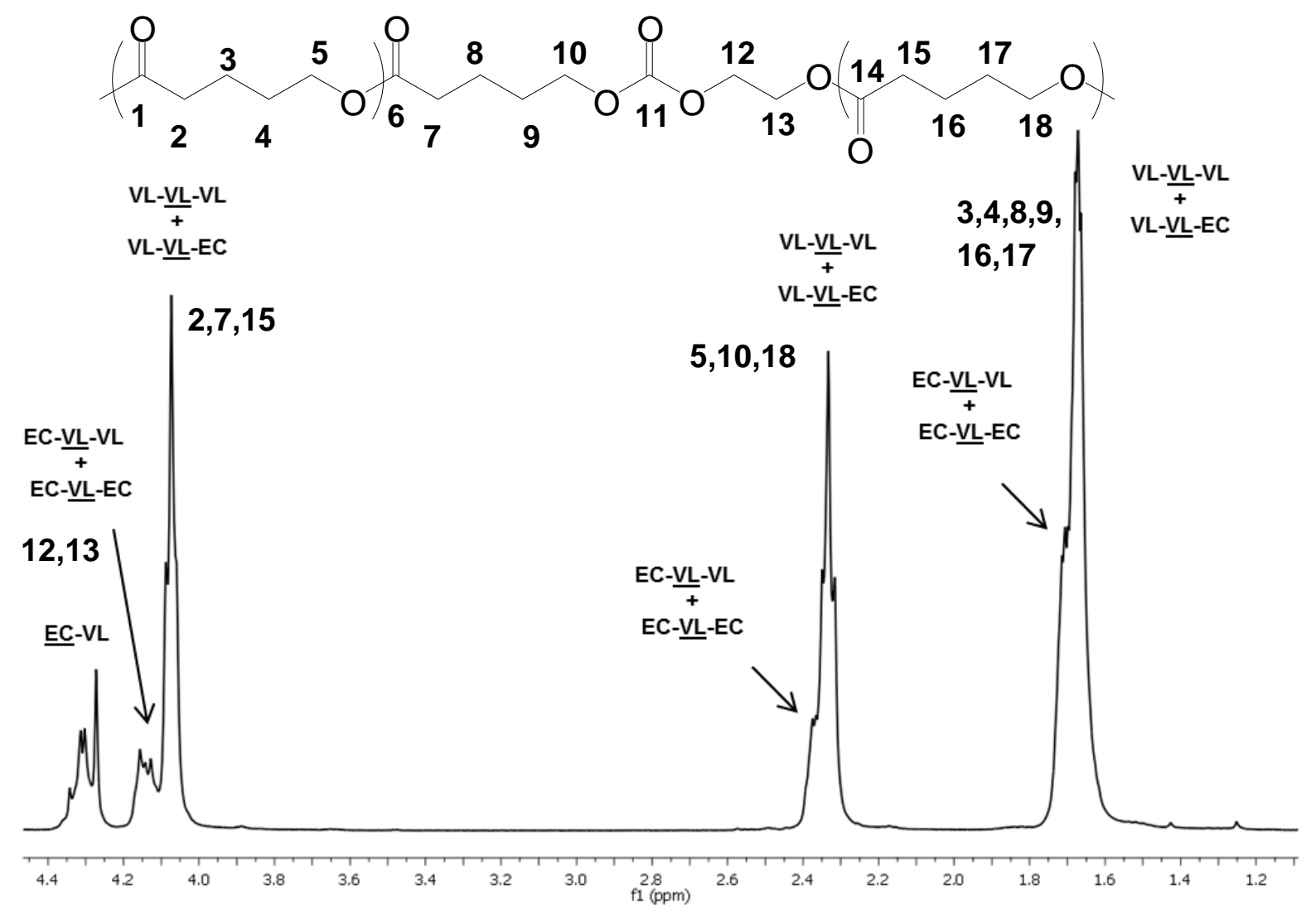


Figure 5. ${ }^{1} \mathrm{H}$ NMR spectrum $\left(400 \mathrm{MHz}, \mathrm{CDCl}_{3}, 23{ }^{\circ} \mathrm{C}\right)$ of a $\mathrm{P}(\mathrm{EC}-\mathrm{co}-\mathrm{VL})$ synthesized from [(NNO)ZnEt] and featuring $13 \mathrm{~mol} \%$ of inserted EC (Table 1, entry 7) $(*$ stands for purposely added EC).

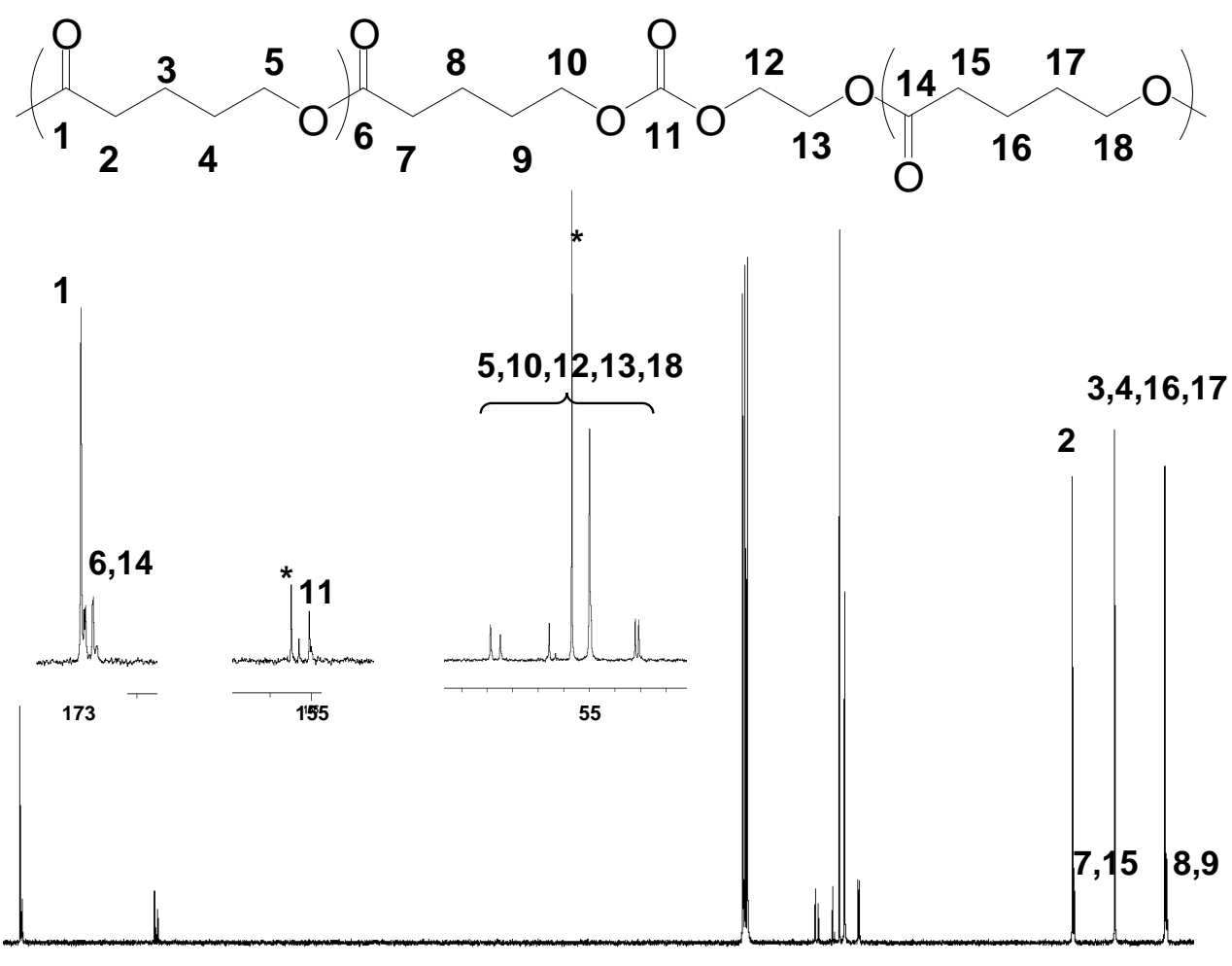

Figure 6. ${ }^{13} \mathrm{C}^{160}\left\{{ }^{1} \mathrm{H}\right\} \mathrm{NMR}$ spectrum $\left(100 \mathrm{MHz}^{100}, \mathrm{CDCl}_{3}, 23{ }^{\circ 0} \mathrm{C}\right)$ of a $\mathrm{P}\left(\mathrm{EC}^{40}-\mathrm{co}-\mathrm{VL}\right)$ synthesized from [(NNO)ZnEt] and featuring $13 \mathrm{~mol} \%$ of inserted EC (Table 1, entry 7) (* stands for purposely added EC).

$P(E C$-co-LLA $)$ copolymers. The representative ${ }^{1} \mathrm{H}$ NMR spectrum of a $\mathrm{P}(\mathrm{EC}-$-co-LLA $)$ random copolymer depicted in Figure 7 with a copolymer featuring $17 \mathrm{~mol} \%$ of EC, showed the awaited PLLA signals $\left(\delta \quad 5.17\right.$ ppm $\quad\left(-\mathrm{OCH}\left(\mathrm{CH}_{3}\right) \mathrm{C}(\mathrm{O})-\right.$ and 1.58 ppm $\left.-\mathrm{OCH}\left(\mathrm{CH}_{3}\right) \mathrm{C}(\mathrm{O})-\right)$, both flanked by a set of lower intensity signals-as noticed on the $\mathrm{P}(\mathrm{EC}-$ co-VL) ${ }^{1} \mathrm{H}$ NMR spectra-, corresponding to EC-LLA junctions. In addition, a broad EC signal was unambiguously observed ( $\delta 4.30 \mathrm{ppm})$. Correspondingly, the ${ }^{13} \mathrm{C}\left\{{ }^{1} \mathrm{H}\right\}$ NMR spectrum showed, in the carbonyl region, a strong resonance resulting from the lactidyl 
moiety $\left(\delta 169.7\right.$ ppm, $\left.-\mathrm{OCH}\left(\mathrm{CH}_{3}\right) C(\mathrm{O})-\right)$ flanked by a significantly less intense resonance $(\delta$ $169.9 \mathrm{ppm}$ ) assigned to $-\mathrm{CH}_{2} \mathrm{OC}(\mathrm{O}) \mathrm{CH}\left(\mathrm{CH}_{3}\right)$ - junctions (Figure 8). ${ }^{78}$ Also, the two signals observed at $\delta 154.34$ and $154.01 \mathrm{ppm}$ were assigned to EC units inserted into PLLA. As commented in the case of EC/BL, EC/VL, and EC/CL, this distinct doubling may result from remote and nearby EC units such as in $E C$-LLA-LLA-EC and $E C$-LLA-EC sequences, respectively, within the copolymer (more likely than $E C-E C$ homosequences). Further assignments of the spectrum were in agreement with literature data. ${ }^{45}$<smiles>[2H]C(OC(C)(C)C)C(=O)OC(C)C(=O)OCCOC(=O)OC(C)C(=O)OC(C)C(=O)OC(C)C(=O)OC(C)C(C)OC(C)C</smiles>

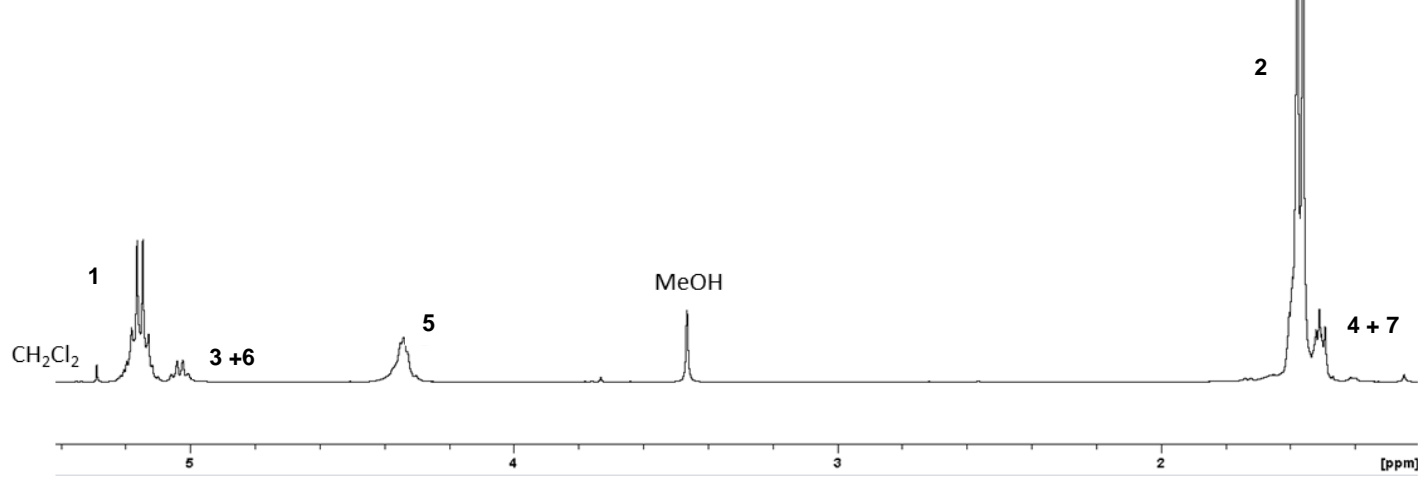

Figure 7. ${ }^{1} \mathrm{H} \mathrm{NMR}$ spectrum $\left(400 \mathrm{MHz}, \mathrm{CDCl}_{3}, 23{ }^{\circ} \mathrm{C}\right)$ of a $\mathrm{P}(\mathrm{EC}-\mathrm{co}$-LLA) synthesized from [(NNO)ZnEt] and featuring $17 \mathrm{~mol} \%$ of inserted EC (Table 2, entry 8). 

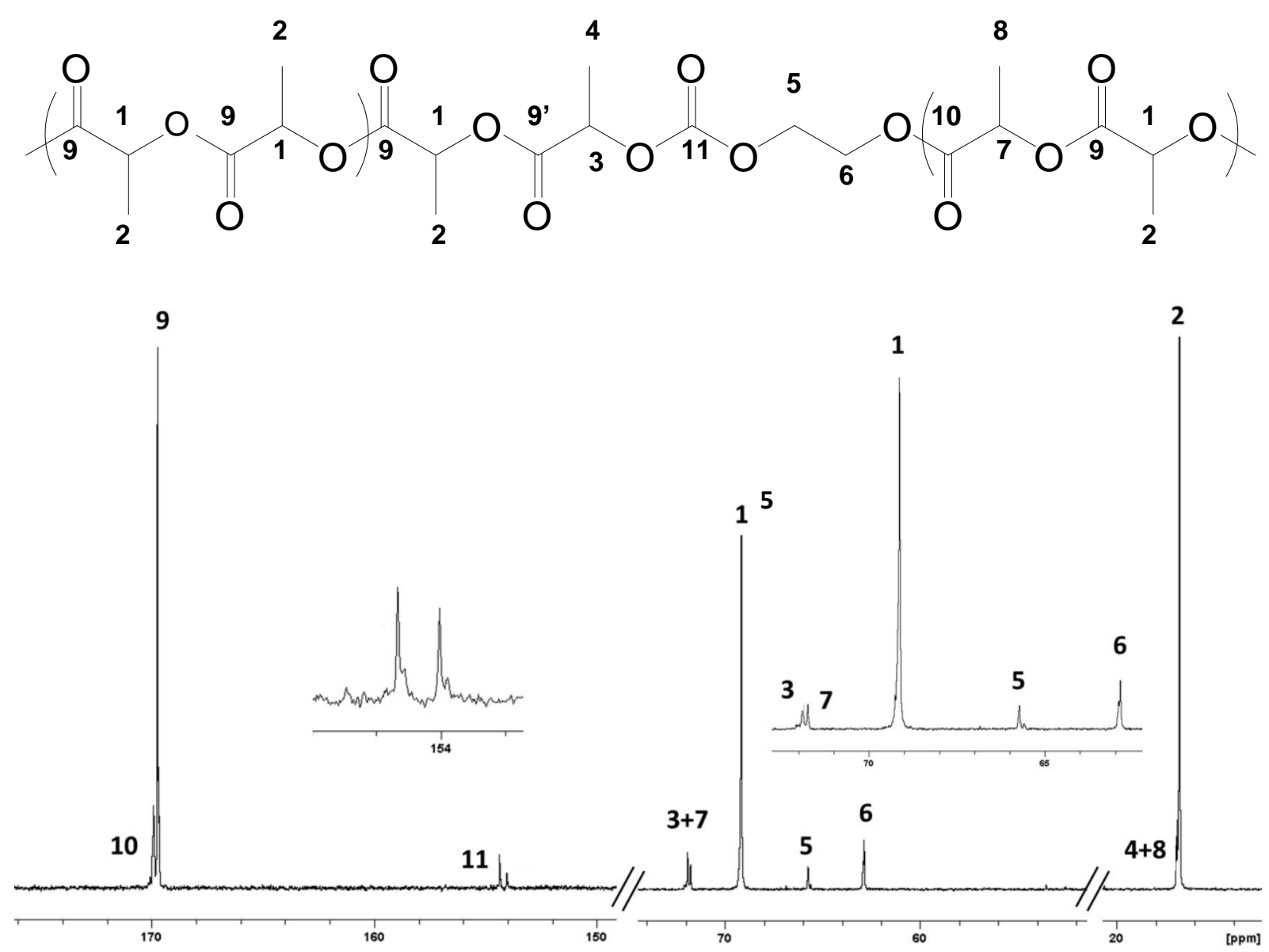

Figure 8. ${ }^{13} \mathrm{C}\left\{{ }^{1} \mathrm{H}\right\}$ NMR spectrum $\left(100 \mathrm{MHz}, \mathrm{CDCl}_{3}, 23{ }^{\circ} \mathrm{C}\right)$ of a $\mathrm{P}(\mathrm{EC}-\mathrm{co}$-LLA $)$ synthesized from [(NNO)ZnEt] and featuring $17 \mathrm{~mol} \%$ of inserted EC (Table 2, entry 8).

Thermal analysis. Thermal characterization of the copolymers was performed by DSC (Table 3). A P(EC-co-BL) featuring $26 \mathrm{~mol} \%$ of EC (Table 1, entry 4) displayed a unique glass transition temperature $T_{g}$ at $-1.6^{\circ} \mathrm{C}$ (Figure S7), a temperature typical of a $\mathrm{PHB}$ commonly ranging from -4 to $+10{ }^{\circ} \mathrm{C} .{ }^{80}$ Similarly, the DSC analysis of a $\mathrm{P}(\mathrm{EC}-\mathrm{co}-\mathrm{VL})$ and $\mathrm{P}(\mathrm{EC}-\mathrm{co}-\mathrm{CL})$ featuring $13-14 \mathrm{~mol} \%$ of EC (Table 1, entries 7,13 ), showed a $T_{\mathrm{g}}$ at $-49.1{ }^{\circ} \mathrm{C}$ and $-59.1^{\circ} \mathrm{C}$, along with a melting temperature $T_{\mathrm{m}}$ of $+30.2^{\circ} \mathrm{C}$ and $+38.5^{\circ} \mathrm{C}$, and a crystallization temperature of $-9.2{ }^{\circ} \mathrm{C}$ and $-2.2{ }^{\circ} \mathrm{C}$, respectively (Figures S8, 9). Incorporation of EC (PEC: $\left.T_{\mathrm{g}}=+10-+28{ }^{\circ} \mathrm{C}\right)$ thus influenced similarly the thermal temperatures of PCL $\left(T_{\mathrm{g}}\right.$ $\left.=-60{ }^{\circ} \mathrm{C}, T_{\mathrm{m}}=+65^{\circ} \mathrm{C}\right)$ and those of PVL $\left(T_{\mathrm{g}}=-63^{\circ} \mathrm{C}, T_{\mathrm{m}}=+60{ }^{\circ} \mathrm{C}\right)$. The glass transition 
and melting temperatures of a $\mathrm{P}(\mathrm{EC}-\mathrm{co}$-LLA) featuring 9 mol\% of EC (Table 2, entry 5) were measured at $T_{g}=53{ }^{\circ} \mathrm{C}$ and $T_{m}=149{ }^{\circ} \mathrm{C}$, respectively (Figure S9). These temperature values were lower than those of a PLLA homopolymer $\left(T_{g}=65^{\circ} \mathrm{C}\right.$ and $\left.T_{m}=175{ }^{\circ} \mathrm{C}\right) .{ }^{57,59}$ The $T_{\mathrm{g}}$ of all the copolymers was found to dependent on the molar ratio of EC:cyclic ester units, in agreement with the Fox theory. All these DSC results supported that the copolymerization of EC with either BL, VL, CL or LLA resulted in random copolymers, with the amount of EC inserted affecting, as expected, the thermal behavior of the resulting random copolymers (Table 3).

Table 3. Thermal characteristics of the PEC-polyester random copolymers.

\begin{tabular}{|c|c|c|c|c|c|}
\hline Copolymer & $\begin{array}{c}\text { EC } \\
\text { inserted }^{\mathrm{a}} \\
(\mathrm{wt} \%)\end{array}$ & $\begin{array}{c}T_{g}{ }^{\mathrm{b}} \\
\left({ }^{\circ} \mathrm{C}\right)\end{array}$ & $T_{g}$, calc. $^{\mathrm{c}}$ & $\begin{array}{l}T_{m}^{\mathrm{b}} \\
\left({ }^{\circ} \mathrm{C}\right)\end{array}$ & $\begin{array}{l}T_{c}{ }^{\mathrm{b}} \\
\left({ }^{\circ} \mathrm{C}\right)\end{array}$ \\
\hline $\mathrm{P}(\mathrm{EC}-c o-\mathrm{BL})$ & 26 & -2 & +5 & - & - \\
\hline $\mathrm{P}(\mathrm{EC}-c o-\mathrm{VL})$ & 12 & -49 & -56 & +30 & -9 \\
\hline $\mathrm{P}(\mathrm{EC}-c o-\mathrm{CL})$ & 11 & -59 & -54 & +38 & -2 \\
\hline $\mathrm{P}(\mathrm{EC}-c o-\mathrm{LLA})$ & 6 & +53 & +61 & +149 & - \\
\hline
\end{tabular}




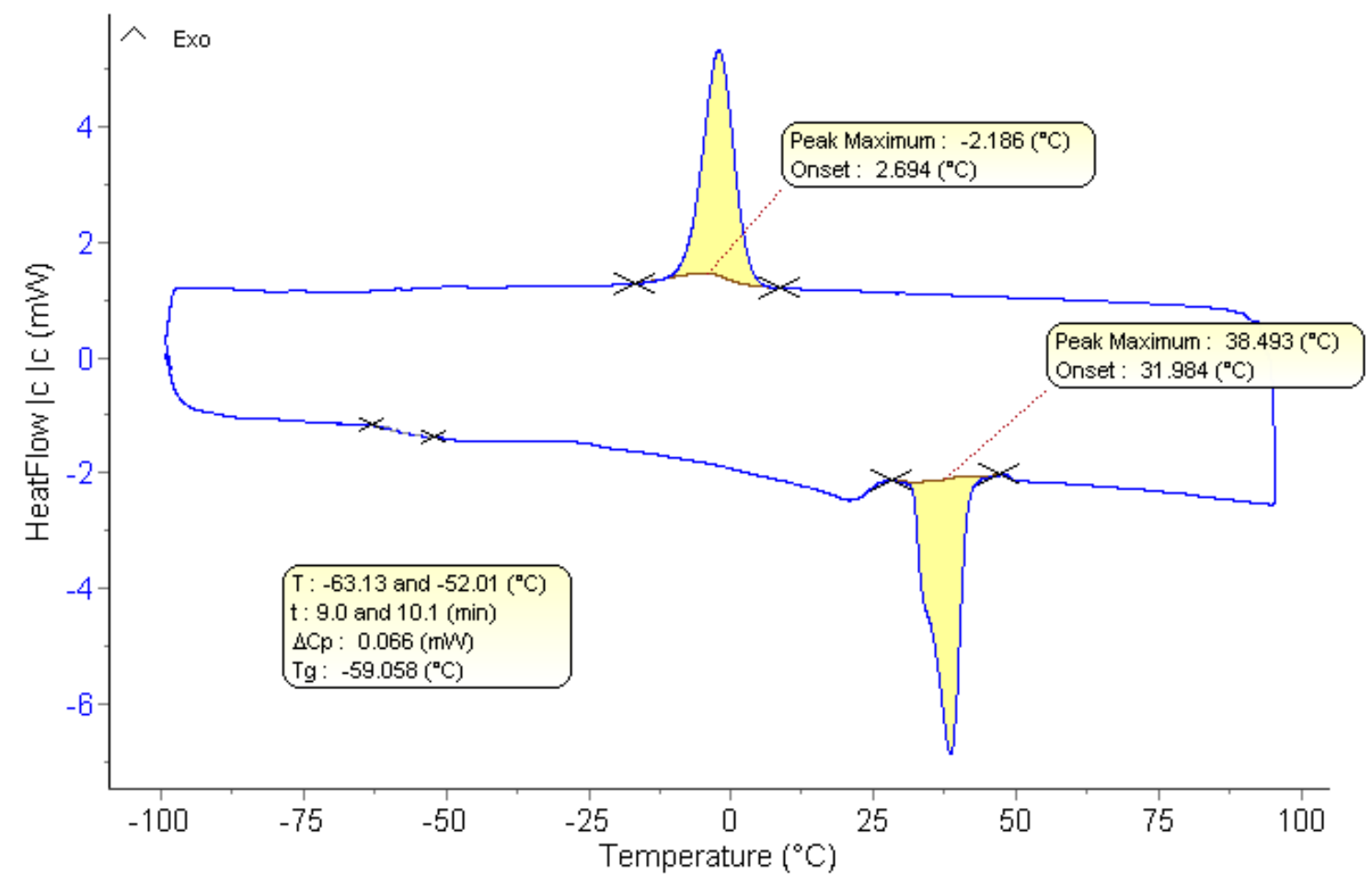

Figure 9. DSC trace of a P(EC-co-CL) featuring $14 \mathrm{~mol} \%$ of EC (Table 1, entry 13).

\section{Conclusion}

Zinc-based and organic catalyst systems, distinct from and less air- and moisture-sensitive than the previously established rare earth-based ones, ${ }^{43-50}$ also ineffective in the EC homopolymerization, have thus been unveiled for the successful controlled copolymerization of EC with lactones or lactide. The copolymerization proceeded without decarboxylation under mild operating conditions (preferentially $60{ }^{\circ} \mathrm{C}$, up to $100{ }^{\circ} \mathrm{C}$; toluene; $0.5-6 \mathrm{~h}$ ) affording copolymers with $M_{\mathrm{n}, \mathrm{SEC}}$ values in the range $c a .6000-93350 \mathrm{~g}^{\mathrm{mol}}{ }^{-1}$ and rather moderate dispersity values $\left(1.24 \leq \emptyset_{\mathrm{M}} \leq 2.15\right)$. The first examples of $\mathrm{EC} / \mathrm{BL}$ random copolymers, featuring up to $26 \mathrm{~mol} \%$ of EC inserted within the polyester, have been prepared from $[(\mathrm{NNO}) \mathrm{ZnEt}] / \mathrm{BnOH}$. This same zinc-based system allowed the successful synthesis of $\mathrm{P}(\mathrm{EC}-\mathrm{co}-\mathrm{VL})$ and $\mathrm{P}(\mathrm{EC}-\mathrm{co}-\mathrm{CL})$ copolymers by copolymerization of EC with the larger 
lactones. Whereas the latter copolymers were already exemplified in several works, ${ }^{43-46}$ the former $\mathrm{P}(\mathrm{EC}-\mathrm{co}-\mathrm{VL})$ copolymers represent, to our knowledge, the second example to date. ${ }^{44}$ In these latter two cases, the largest EC content recovered in the copolymer could be improved from the previously reported limit of $10 \mathrm{~mol} \%$ and $31 \mathrm{~mol} \%$ obtained from $\left[\left(\mathrm{C}_{5} \mathrm{Me}_{5}\right)_{2} \mathrm{SmMe}(\mathrm{THF})\right],{ }^{44}$ to 23 and $37 \mathrm{~mol} \%$, respectively. The organic guanidine TBD in the presence of $\mathrm{BnOH}$ afforded up to $38 \mathrm{~mol} \%$ of EC inserted within the PCL chains. The zinc diaminophenolate complex associated to $\mathrm{BnOH}$ also enabled to increase the EC extent within a PLA chain, from the previously established amount of $4 \%$ reached from $\mathrm{SmI}_{2} / \mathrm{Sm},{ }^{45}$ up to $17 \mathrm{~mol} \%$. In comparison, the $\left[\left(\mathrm{BDI}^{\mathrm{iPr}}\right) \mathrm{Zn}\left\{\mathrm{N}\left(\mathrm{SiMe}_{3}\right)_{2}\right\}\right]$ system remained less efficient in inserting carbonate units along the polyester chains, with $18 \mathrm{~mol} \%$ and $5 \mathrm{~mol} \%$ of EC incorporated within the ultimate $\mathrm{P}(\mathrm{EC}-\mathrm{co}-\mathrm{BL})$ and $\mathrm{P}(\mathrm{EC}-\mathrm{co}$-LLA), respectively. On the other hand, the aluminum triflate/ $\mathrm{BnOH}$ system evaluated in the $\mathrm{EC} / \mathrm{BL}$ and $\mathrm{EC} / \mathrm{CL}$ copolymerizations significantly promoted decarboxylation. The [(NNO)ZnEt]/BnOH catalytic system thus turned out as the most active and productive one so far disclosed in the successful simultaneous ring-opening copolymerization of EC with VL or CL, without decarboxylation. The microstructural analyses of these EC/BL, VL, CL, LLA copolymers assessed by ${ }^{1} \mathrm{H}$, and in particular ${ }^{13} \mathrm{C}\left\{{ }^{1} \mathrm{H}\right\} \mathrm{NMR}$ revealed the presence of signals previously never described and assigned to the presence of consecutive EC units within the random copolymers. Thermal transition temperatures measured by DSC further supported the random nature of these copolymers.

\section{Acknowledgements}

The authors gratefully thank Total Petrochemicals Co. for financial support of this research (Ph.D. grant to W. G.) and the Region Bretagne and Rennes Métropole for equipment support. X. Michel is also gratefully acknowledged for completing DSC analyses. 
Supporting information includes the complementing ${ }^{1} \mathrm{H}$ and ${ }^{13} \mathrm{C}\left\{{ }^{1} \mathrm{H}\right\}$ NMR spectra and DSC traces of the commercial PEC sample, EC/BL, EC/VL, EC/CL and EC/LLA copolymers. 


\section{Supporting Information}

\section{List of figures}

Figure S1. ${ }^{1} \mathrm{H}$ NMR spectrum $\left(400 \mathrm{MHz}, \mathrm{CDCl}_{3}, 23{ }^{\circ} \mathrm{C}\right)$ of a commercial $\mathrm{PEC}\left(M_{\mathrm{n}}=250000\right.$ g.mol $\left.{ }^{-1}, \bigoplus_{\mathrm{M}}=1.9\right)$ prepared from $\mathrm{CO}_{2} /$ ethylene oxide copolymerization.

Figure S2. ${ }^{13} \mathrm{C}$ NMR spectrum $\left(400 \mathrm{MHz}, \mathrm{CDCl}_{3}, 23{ }^{\circ} \mathrm{C}\right)$ of a commercial $\mathrm{PEC}\left(M_{\mathrm{n}}=\right.$ 250000 g.mol $\left.{ }^{-1}, \bigoplus_{\mathrm{M}}=1.9\right)$ prepared from $\mathrm{CO}_{2} /$ ethylene oxide copolymerization.

Figure S3. ${ }^{1} \mathrm{H}$ NMR spectrum $\left(400 \mathrm{MHz}, \mathrm{CDCl}_{3}, 23{ }^{\circ} \mathrm{C}\right)$ of a copolymer synthesized by copolymerization of EC/CL mediated by $\mathrm{Al}(\mathrm{OTf})_{3} / \mathrm{BnOH}$ (Table 1, entry 12).

Figure S4. ${ }^{13} \mathrm{C}\left\{{ }^{1} \mathrm{H}\right\}$ NMR spectrum $\left(100 \mathrm{MHz}, \mathrm{CDCl}_{3}, 23{ }^{\circ} \mathrm{C}\right)$ of a copolymer synthesized by copolymerization of EC/CL mediated by $\mathrm{Al}(\mathrm{OTf})_{3} / \mathrm{BnOH}$ (Table 1, entry 12$)$.

Figure S5. ${ }^{13} \mathrm{C} \mathrm{NMR}$ spectrum $\left(100 \mathrm{MHz}, \mathrm{CDCl}_{3}, 23{ }^{\circ} \mathrm{C}\right)$ of a $\mathrm{P}(\mathrm{EC}-\mathrm{co}$-BL $)$ synthesized from [(NNO)ZnEt] and featuring $26 \mathrm{~mol} \%$ of inserted EC (Table 1, entry 4$)$ (* stands for residual $\mathrm{EC})$.

Figure S6. Carbonyl region of the ${ }^{13} \mathrm{C}\left\{{ }^{1} \mathrm{H}\right\}$ NMR spectrum $\left(100 \mathrm{MHz}, \mathrm{CDCl}_{3}, 23{ }^{\circ} \mathrm{C}\right)$ of a mixture of a $\mathrm{P}(\mathrm{EC}-\mathrm{co}-\mathrm{CL})$ featuring $28 \mathrm{~mol} \%$ of inserted EC (Table 1, entry 14) and a commercial PEC $\left(M_{\mathrm{n}}=250000 \mathrm{~g} \cdot \mathrm{mol}^{-1}, \bigoplus_{\mathrm{M}}=1.9\right.$ prepared from $\mathrm{CO}_{2} /$ ethylene oxide copolymerization.

Figure S7. DSC trace of a P(EC-co-BL) featuring 26 mol\% of EC (Table 1, entry 4).

Figure S8. DSC trace of a $\mathrm{P}(\mathrm{EC}-\mathrm{co}-\mathrm{VL})$ featuring $13 \mathrm{~mol} \%$ of EC (Table 1, entry 7).

Figure S9. DSC trace of a P(EC-co-LLA) featuring 7 mol\% of EC (Table 2, entry 5). 


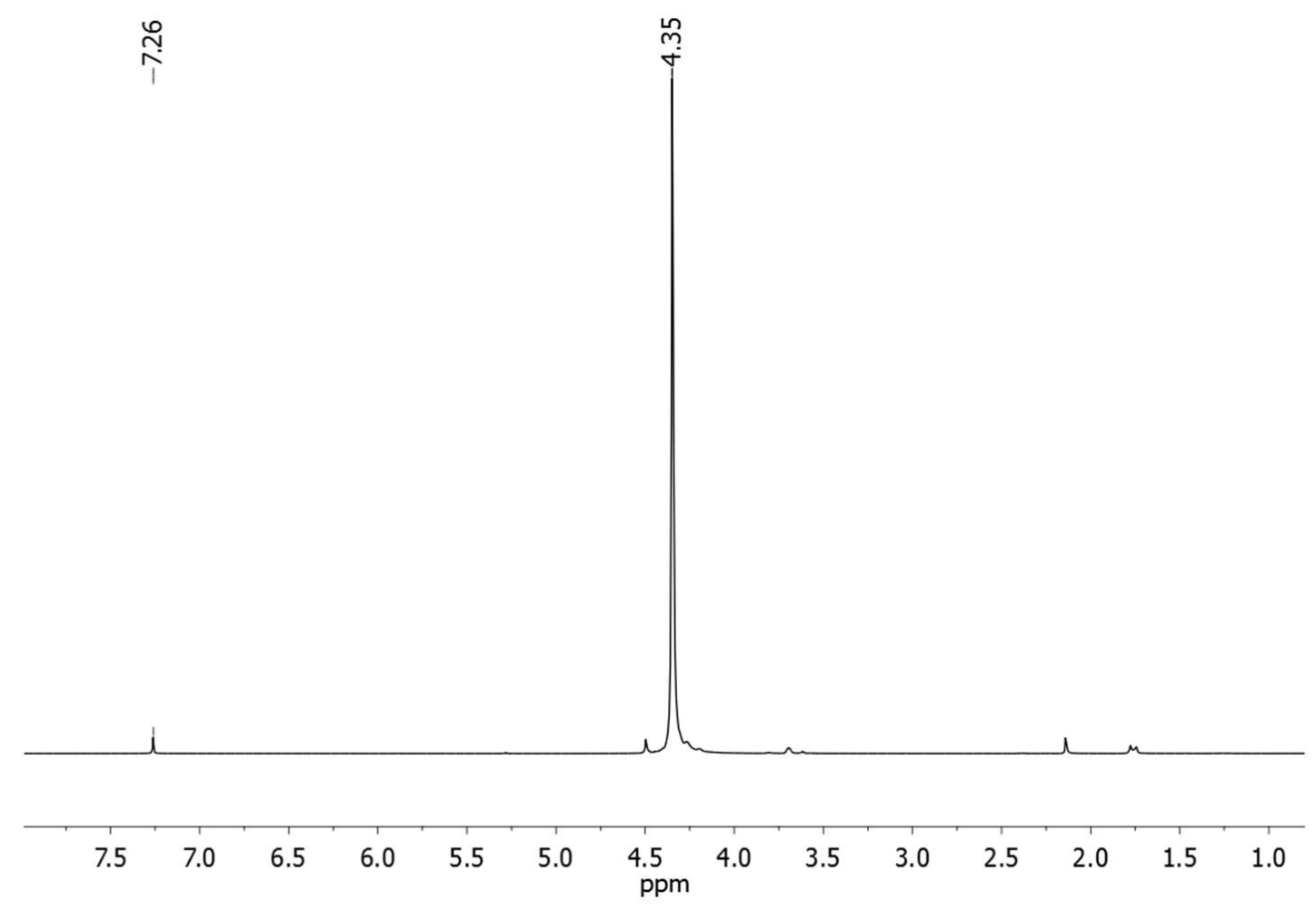

Figure S1. ${ }^{1} \mathrm{H}$ NMR spectrum $\left(400 \mathrm{MHz}, \mathrm{CDCl}_{3}, 23{ }^{\circ} \mathrm{C}\right)$ of a commercial $\mathrm{PEC}\left(M_{\mathrm{n}}=250000\right.$ g.mol $\left.{ }^{-1}, \bigoplus_{\mathrm{M}}=1.9\right)$ prepared from $\mathrm{CO}_{2} /$ ethylene oxide copolymerization.

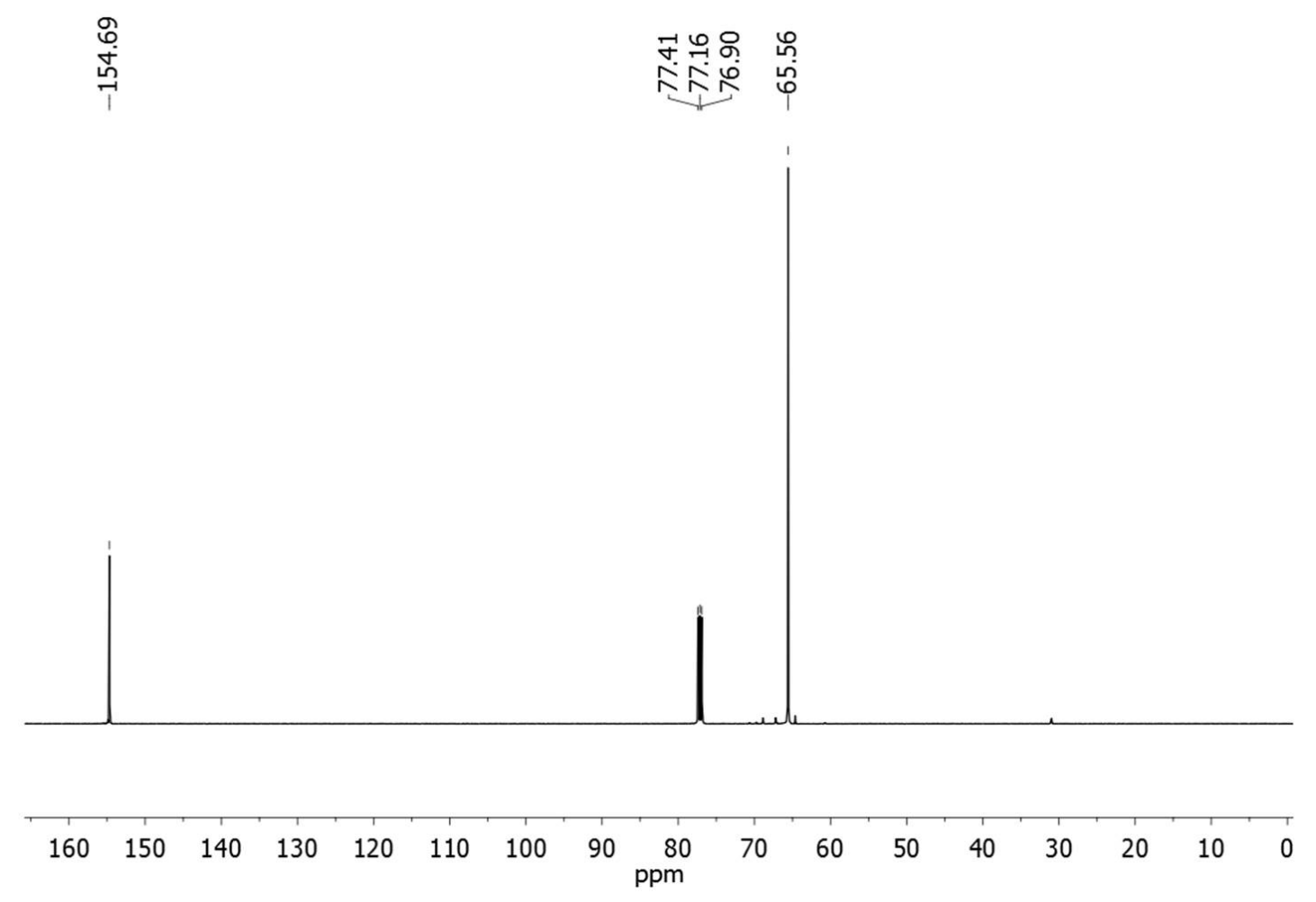

Figure S2. ${ }^{13} \mathrm{C}$ NMR spectrum $\left(400 \mathrm{MHz}, \mathrm{CDCl}_{3}, 23{ }^{\circ} \mathrm{C}\right)$ of a commercial $\mathrm{PEC}\left(M_{\mathrm{n}}=\right.$ 250000 g.mol $\left.{ }^{-1}, \bigoplus_{\mathrm{M}}=1.9\right)$ prepared from $\mathrm{CO}_{2} /$ ethylene oxide copolymerization. 


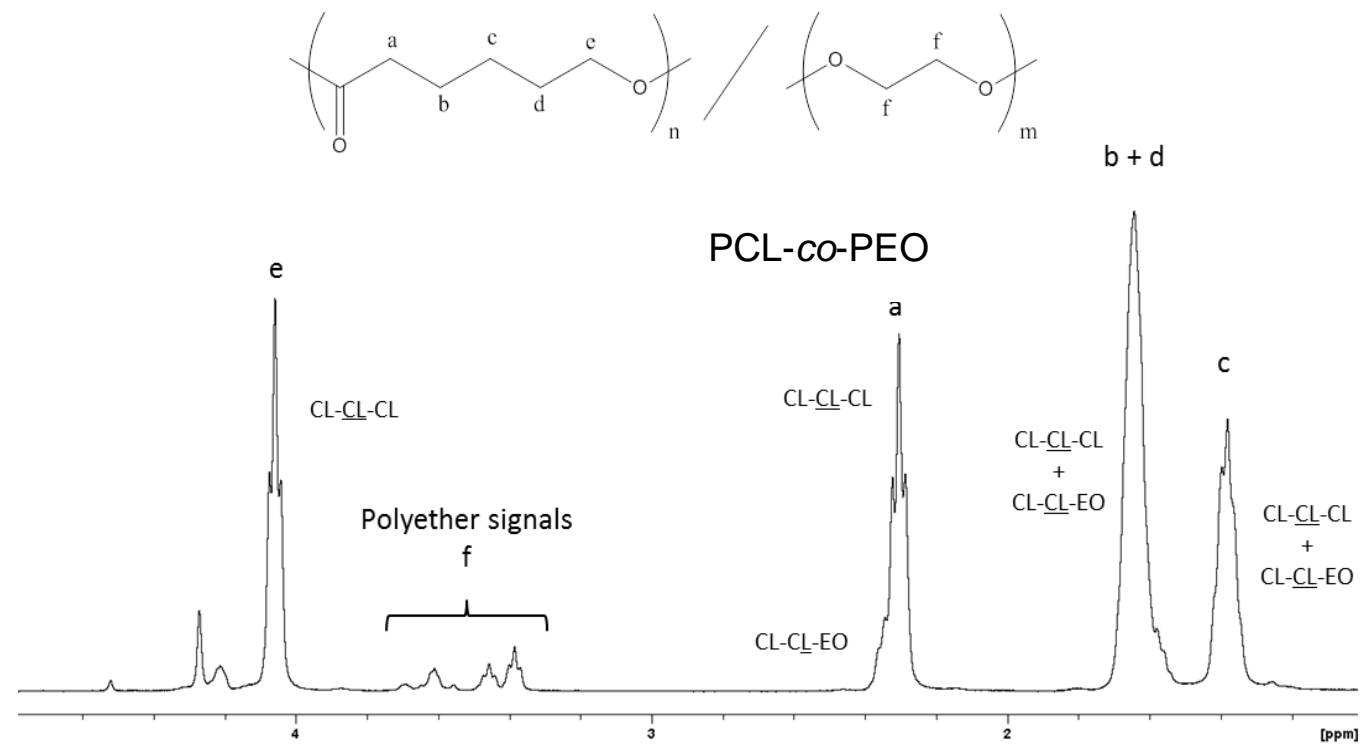

Figure S3. ${ }^{1} \mathrm{H}$ NMR spectrum $\left(400 \mathrm{MHz}, \mathrm{CDCl}_{3}, 23{ }^{\circ} \mathrm{C}\right)$ of a copolymer synthesized by copolymerization of EC/CL mediated by $\mathrm{Al}(\mathrm{OTf})_{3} / \mathrm{BnOH}$ (Table 1 , entry 12$)$.

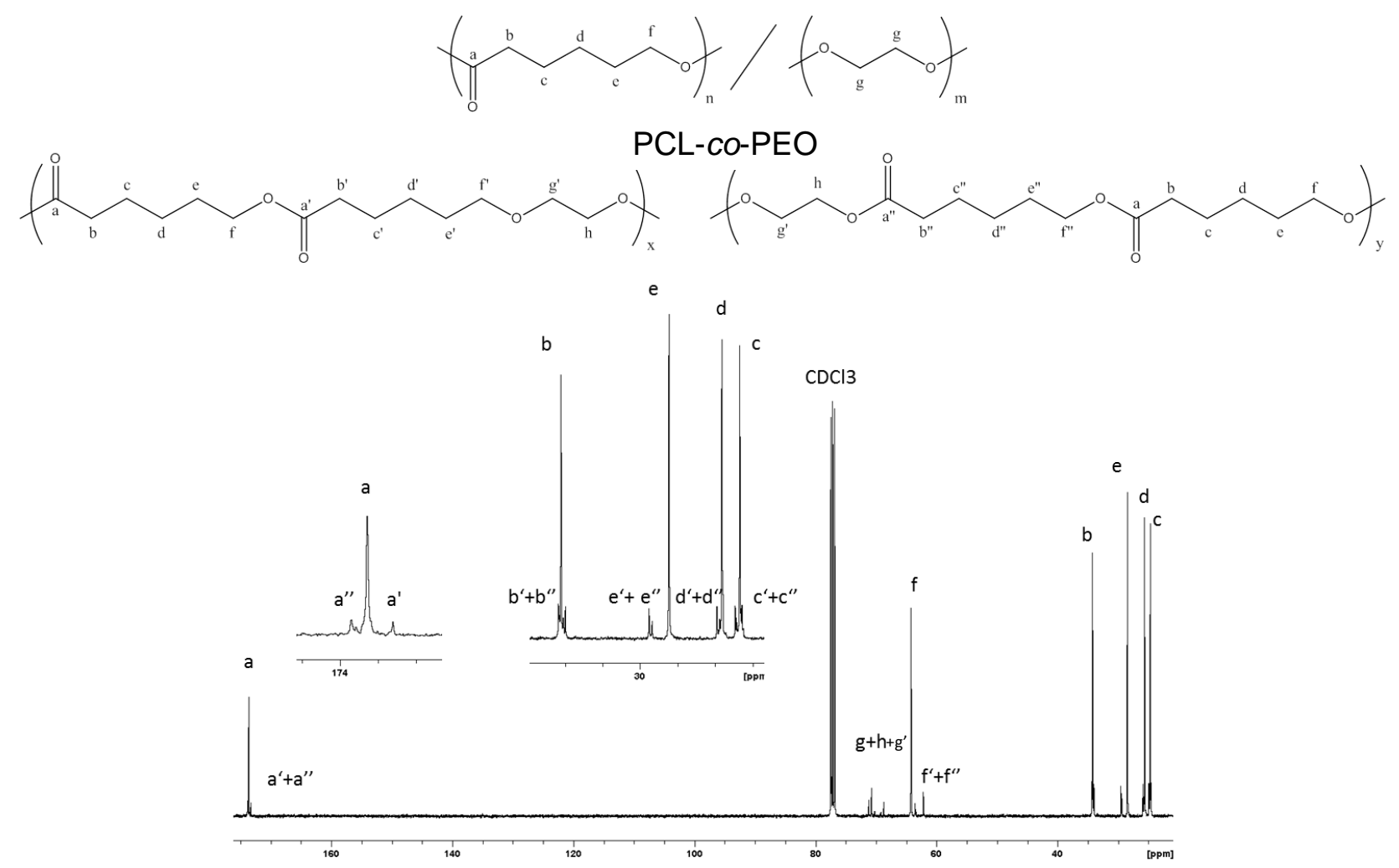

Figure S4. ${ }^{13} \mathrm{C}\left\{{ }^{1} \mathrm{H}\right\}$ NMR spectrum $\left(100 \mathrm{MHz}, \mathrm{CDCl}_{3}, 23{ }^{\circ} \mathrm{C}\right)$ of a copolymer synthesized by copolymerization of EC/CL mediated by $\mathrm{Al}(\mathrm{OTf})_{3} / \mathrm{BnOH}$ (Table 1, entry 12 ). 


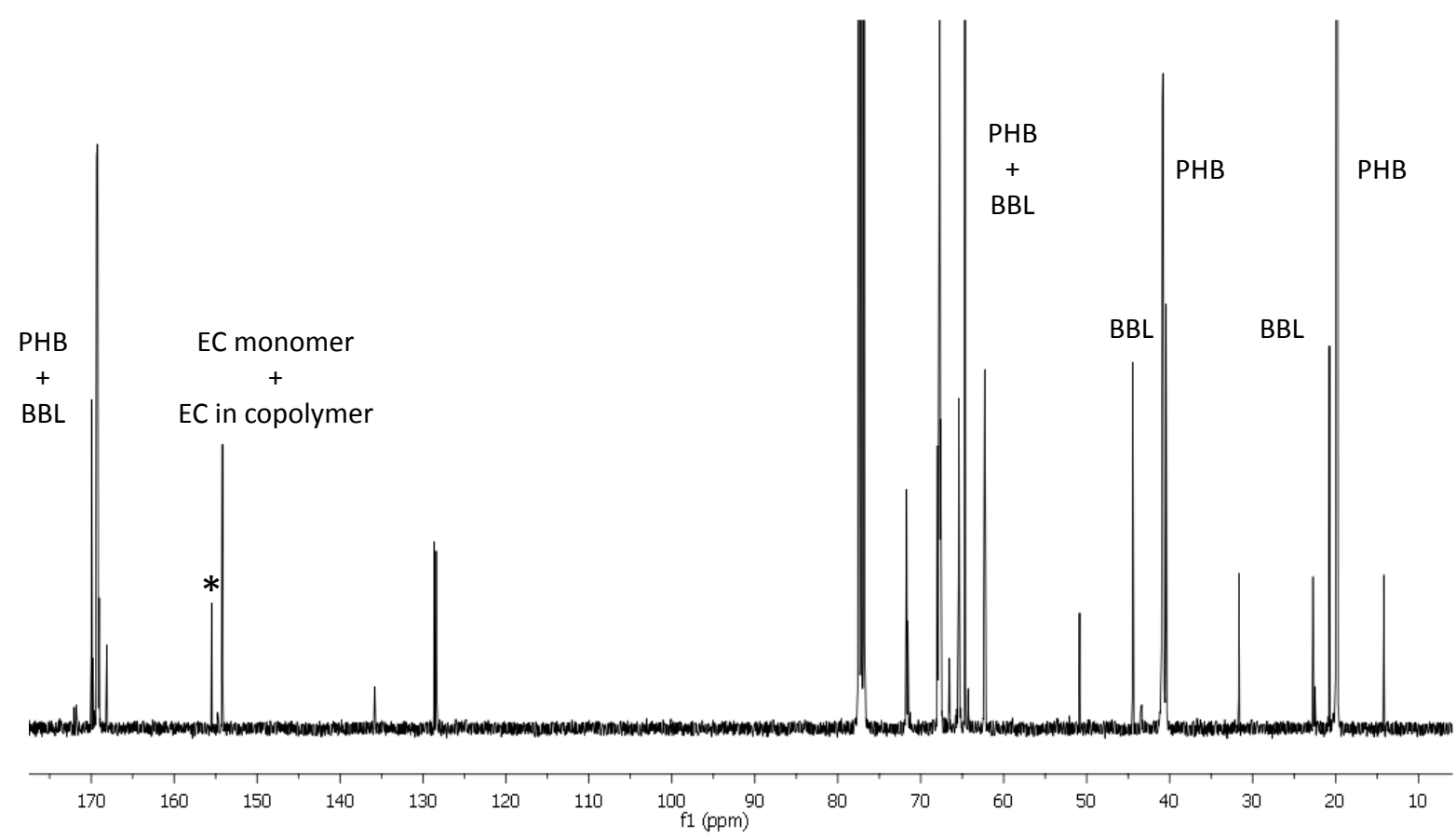

Figure S5. ${ }^{13} \mathrm{C}$ NMR spectrum $\left(100 \mathrm{MHz}, \mathrm{CDCl}_{3}, 23{ }^{\circ} \mathrm{C}\right)$ of a $\mathrm{P}(\mathrm{EC}-\mathrm{co}$-BL $)$ synthesized from [(NNO)ZnEt] and featuring $26 \mathrm{~mol} \%$ of inserted EC (Table 1, entry 4) (* stands for residual $\mathrm{EC})$.

PEC Mn=250 000 g.mol ${ }^{-1}$

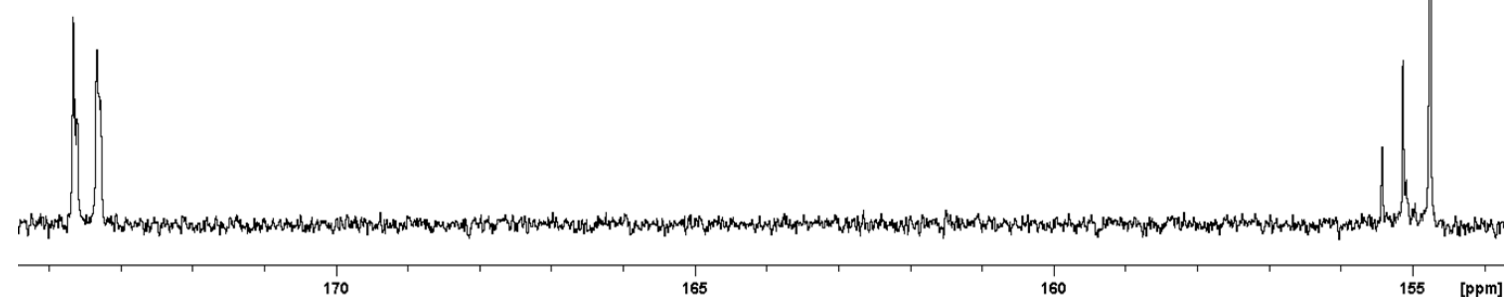

Figure S6. Carbonyl region of the ${ }^{13} \mathrm{C}\left\{{ }^{1} \mathrm{H}\right\}$ NMR spectrum $\left(100 \mathrm{MHz}, \mathrm{CDCl}_{3}, 23{ }^{\circ} \mathrm{C}\right)$ of a mixture of a P(CL-co-EC) featuring $28 \mathrm{~mol} \%$ of inserted EC (Table 1, entry 14) and a commercial PEC $\left(M_{\mathrm{n}}=250000 \mathrm{~g} \cdot \mathrm{mol}^{-1}, \bigoplus_{\mathrm{M}}=1.9\right.$ prepared from $\mathrm{CO}_{2} /$ ethylene oxide copolymerization. 


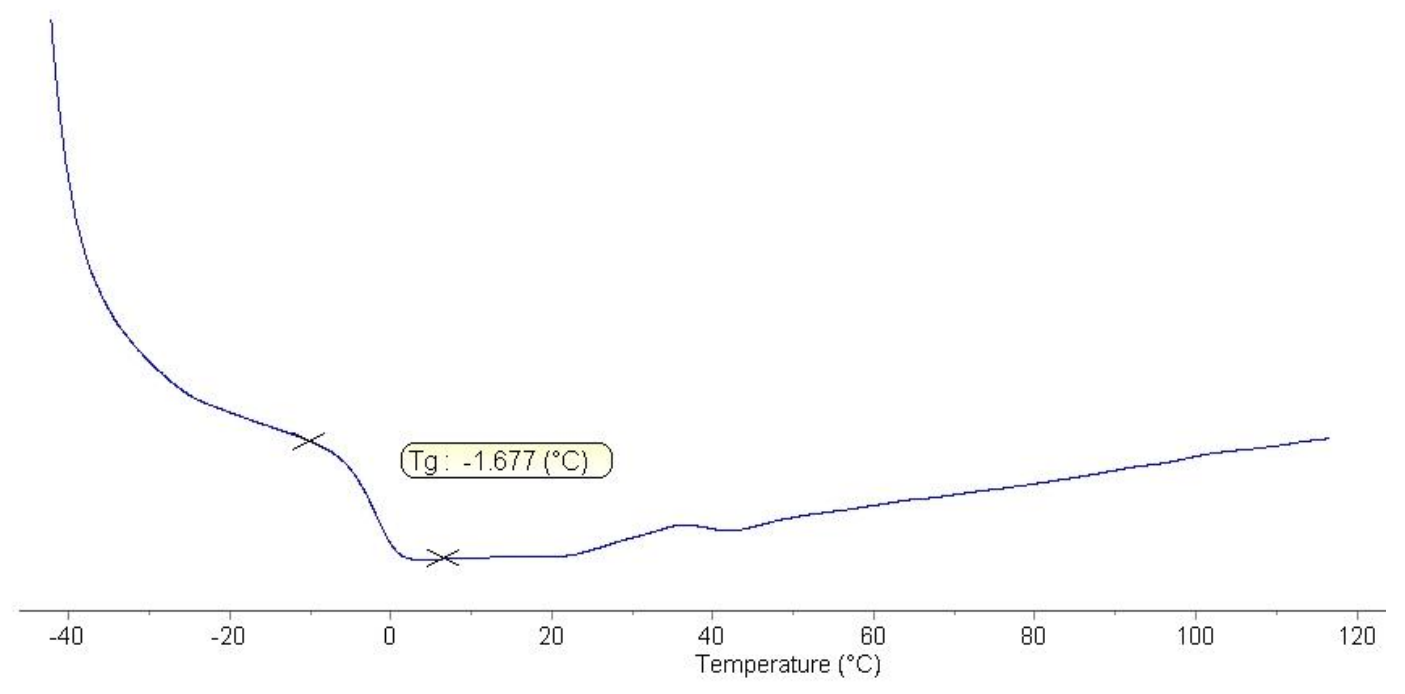

Figure S7. DSC trace of a P(EC-co-BL) featuring 26 mol\% of EC (Table 1, entry 4).

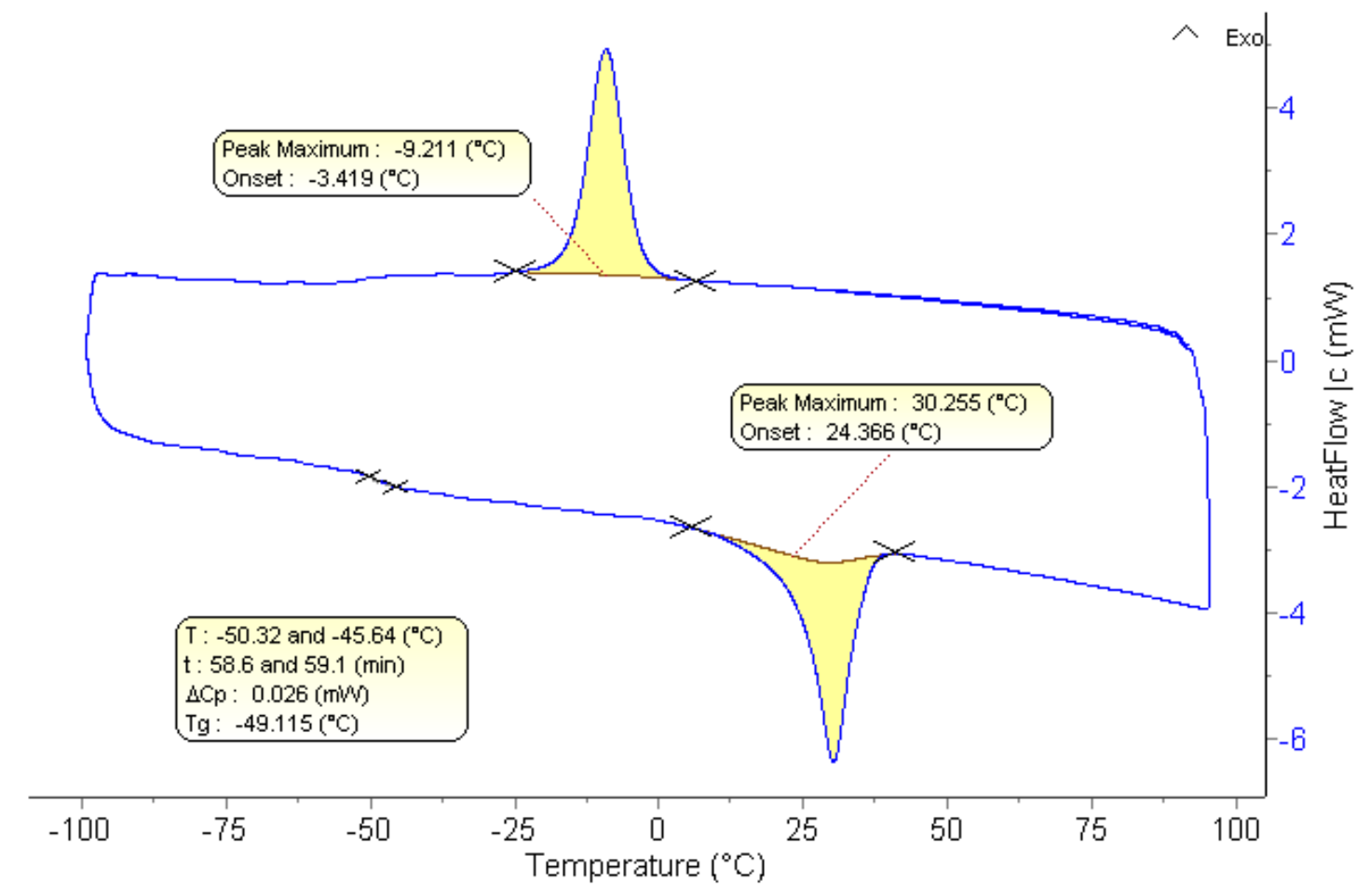

Figure S8. DSC trace of a P(EC-co-VL) featuring 13 mol\% of EC (Table 1, entry 7). 


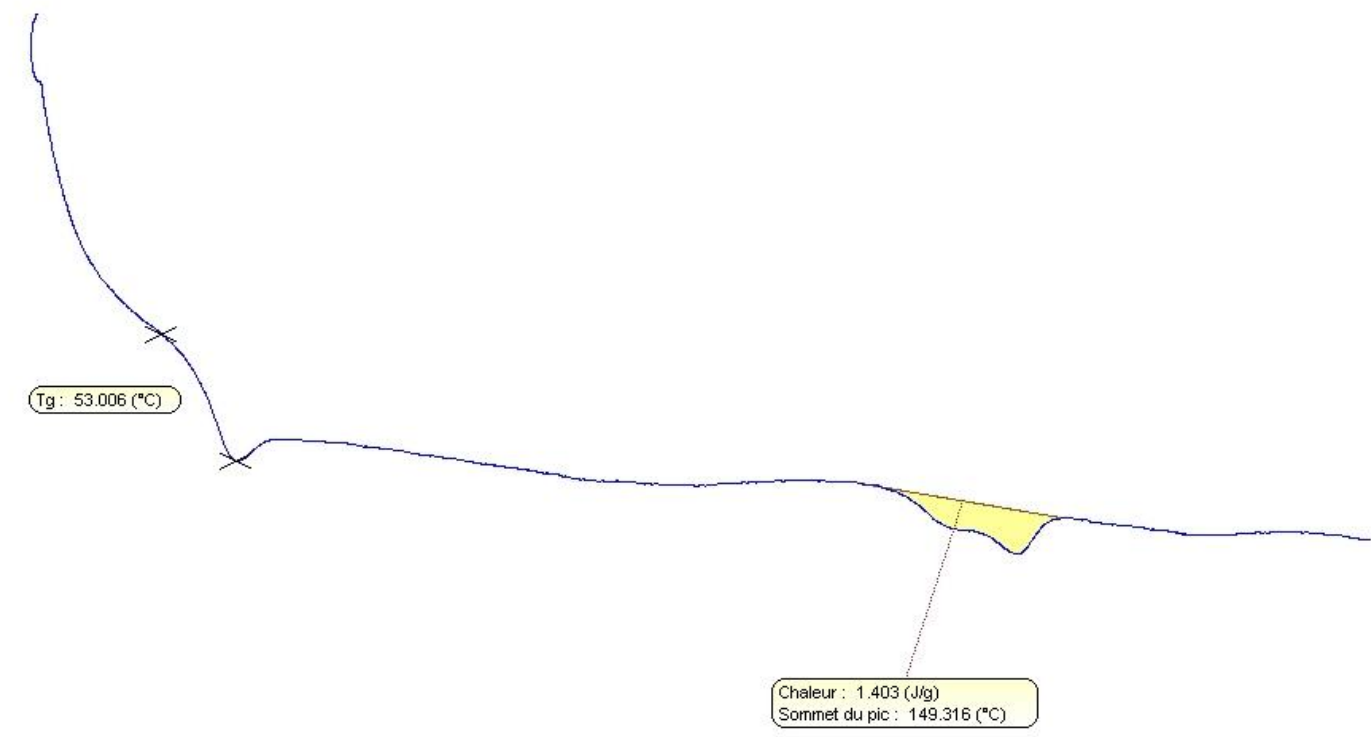

40

60

80

$100 \quad 120$

140

160

180

2l

Figure S9. DSC trace of a P(EC-co-LLA) featuring 9 mol\% of EC (Table 2, entry 5). 


\section{References and Notes}

1 Advances in Polycarbonates. Proceedings of Symposium of the American Chemical Society, March 2003, Washington, DC; Brunelle, D J, Korn, M R, Eds; ACS Symposium Series 898; American Chemical Society: Washington, DC, 2005.

2 J. Feng, R.-X. Zhuo, X.-Z. Zhang, Prog. Polym. Sci. 2012, 37, 211-236.

3 F. Suriano, O. Coulembier, J. L. Hedrick, P. Dubois, Polym. Chem. 2011, 2, 528-533.

4 B. D. Ulery, L. S. Nair, C. T. Laurencin, J. Polym. Sci., Part B: Polym. Phys. 2011, 49, 832-864.

5 S. Fukuoka, M. Tojo, H. Hachiya, M. Aminaka, K. Hasegawa, Polym. J. 2007, 39, 91114.

6 S. Fukuoka, M. Kawamura, K. Komiya, M. Tojo, H. Hachiya, K. Hasegawa, M. Aminaka, H. Okamoto, I. Fukawa, S. Konno, Green Chem., 2003, 5, 497-507

7 M. Yamamoto, N. Uchimura, K. Adachi, Y. Tsukahara, Des. Monomers Polym. 2010, 13, 445-458.

8 M. Mennicken, R. Nagelsdiek, H. Keul, H. Höcker, Macromol. Chem. Phys. 2004, 205, 143-153.

9 M. R. Kember, A. Buchard, C. K. Williams, Chem. Commun. 2011, 47, 141-163.

10 P. P. Pescarmona, M. Taherimehr, Catal. Sci. \& Technol. 2012, 2, 2169-2187.

11 G. W. Coates, D. R. Moore. Angew. Chem. Int. Ed. 2004, 43, 6618-6639.

12 S. Klaus, M. W. Lehenmeier, C. E. Anderson, B. Rieger, Coord. Chem. Rev. 2011, 255, 1460-1479.

13 D. Darensbourg, in Synthetic Biodegradable Polymers, eds B. Rieger, A. Künkel, G. W. Coates, R. Reichardt, E. Dinjus, T. A. Zevaco, Springer, Berlin Heidelberg, 2012, p. 127.

14 X.-B. Lu, W. M. Ren, G.-P. Wu, Acc. Chem. Res. 2012, 45, 1721-1735.

15 G. W. Coates, R. C. Jeske, in Handbook of Green Chemistry, Eds, P. T. Anastas, R. H. Crabtree, 2009, 1, 343-373.

16 M. Taherimehr, S. M. Al-Amsyar, C. J. Whiteoak, A. W. Kleij, P. P. Pescarmona, Green Chem., 2013, 15, 3083-3090.

17 C. Robert, T. Ohkawara, K. Nozaki, Chem. - A Eur. J., 2014, 20, 4789-4795.

18 G. Rokicki, P. G. Parzuchowski, Polym. Sci.: A Comprehensive Reference, 2012, 247308.

19 H. Keul, in Handbook of Ring-Opening Polymerization, Eds P. Dubois, O. Coulembier, J.-M. Raquez, Weinheim, Wiley-VCH, 2009, 307-327.

20 S. Tempelaar, L. Mespouille, O. Coulembier, P. Dubois, A. P. Dove, Chem. Soc. Rev. 2013, 42, 1312-1336.

21 T. Endo, Y. Shibasaki, F. Sanda, J. Polym. Sci., Part A: Polym. Chem. 2002, 40, 21902198.

22 W. Guerin, A. K. Diallo, E. Kirilov, M. Helou, M. Slawinski, J.-M. Brusson, J.-F. Carpentier, S. M. Guillaume, Macromolecules, 2014, 47, 4230-4235.

23 K. Tezuka, K. Komatsu, O. Haba, Polym. J., 2013, 45,1183-1187.

24 G. Odian, Principles of Polymerization, 4th Edition. Hoboken, New Jersey: Wiley Interscience, John Wiley \& Sons, Inc.; 2004.

25 S. Slomkowski, A. Duda, in Ring-Opening Polymerization, Ed, D. J. Brunelle, New York, Hanser Publisher, 1993, p. 87-128.

26 L. Vogdanis, B. Martens, H. Uchtmann, F. Hensel, W. Heitz, Die Makromolekulare Chemie., 1990, 191, 465-472.

27 J.-C. Lee, M. H. Litt, Macromolecules, 2000, 33, 1618-1627. 
L. Vogdanis, W. Heitz, Die Makromolekulare Chemie, Rapid Commun. 1986, 7, 543547.

A. G. Patil, U. R. Kapadi, D. G. Hundiwale, J. Sci. Ind. Res. 2005, 64, 364-366.

J. I. Kadokawa, Y. Iwasaki, H. Tagaya, Macromol. Rapid Commun. 2002, 23, 757-760.

R. F. Storey, D. C. Hoffman, Macromolecules, 1992, 25, 5369-5382.

R. Storey, D; Hoffman, Polym. Bull. 1991, 27, 267-274.

M. Acemoglu, F. Nimmerfall, S. Bantle, G. H. Stoll, J. Controlled Realease, 1997, 49, 263-276.

L. Ubaghs, M. Waringo, K. Helmut, H. Höcker, Macromolecules, 2004, 37, 6755-6762

L. Ubaghs, C. Novi, H. Keul, H. Höcker, Macromol Chem Phys., 2004, 205, 888-896.

K. Soga, Y. Tazuke, S. Hosoda, S. Ikeda, J. Polym. Sci.: Polym. Chem., 1977, 15, 219229.

S. Kéki, J. Török, G. Deák, M. Zsuga, Macromolecules, 2001, 34, 6850-6857.

S. Kéki, J. Török, G. Deák, M. Zsuga, Macromol. Symp., 2004, 215, 141-150.

O. Haba, H. Tomizuka, T. Endo, Macromolecules, 2005, 38, 3562-3563.

M. Azechi, K. Matsumoto, T. Endo, J. Polym. Sci., Part A: Polym. Chem. 2013, 51,16511655 .

Initiators reported in the literature for the ROP of $\mathrm{EC}$ : ${ }^{t} \mathrm{BuP}_{4}, \mathrm{KOH}, \mathrm{KOMe}, \mathrm{K}_{2} \mathrm{CO}_{3}$, $\mathrm{Al}(\mathrm{acac})_{3}, \mathrm{Ti}\left(\mathrm{O}^{t} \mathrm{Bu}\right)_{4}$, alkaline or alkaline earth metals and ammonium borates and titanates, dibutyltin diacetate, dibutyltin dilaurate (DBTL), dibutyltin dimethoxide, sodium stannate trihydrate, and 1-butyl-3-methylimidazolium chloroaluminate ([bmim $] \mathrm{Cl}-\mathrm{AlCl}_{3}$ or 1-butyl-3-methylimidazolium chlorostannate $\left([\mathrm{bmim}] \mathrm{Cl}_{-} \mathrm{SnCl}_{2}\right)$ ionic liquids; Initiators reported in the literature for the ROP of PC: $\mathrm{NEt}_{3}, \mathrm{PPh}_{3}, \mathrm{KOH}, \mathrm{LiOMe}$, $\mathrm{ZnEt}_{2}, \mathrm{ZnCl}_{2}, \mathrm{Zn}(\mathrm{acac})_{2}, \mathrm{AlCl}_{3}, \mathrm{AlEt}_{3}, \mathrm{AlEt}_{2} \mathrm{Cl}, \mathrm{AlEtCl}_{2}, \mathrm{Al}(\mathrm{acac})_{3}, \mathrm{Ti}(\mathrm{OBu})_{4}, \mathrm{FeCl}_{3}$. Reactions were typically performed at $120-250{ }^{\circ} \mathrm{C}$.

Initiators reported in the literature for the ROP of MBCG: $n-\mathrm{BuLi}, \mathrm{MO}^{t} \mathrm{Bu},(\mathrm{M}=\mathrm{Li}, \mathrm{Na}$, $\mathrm{K}$ ), or 1,8-diazabicyclo[5.4.0]undec-7-en (DBU); of $\mathrm{CHC}: \quad \mathrm{KO}^{t} \mathrm{Bu}, \quad$ 1,5,7triazabicyclo[4.4.0]dec-5-ene (TBD), zinc or yttrium complexes.

W. J. Evans, H. Katsumata, Macromolecules, 1994, 27, 4011-4013.

H. Shirahama, A. KanetaniI, H. Yasuda, Polym. J., 2000, 32, 280-286.

S. Agarwal, N. Naumann, X. Xie, Macromolecules. 2002, 35, 7713-7717.

F. Chen F, W. Zhu, N. Xu, Z. Shen, J. Polym. Sci., Part A: Polym. Chem., 2008, 46, 4050-4055.

N. Xu, X. Liu, Y. Liu, W. Zhu, F. Chen, Z. Shen, J. Appl. Polym. Sci., 2010, 115, 46-51.

M. Yan, H. Yang, X. Xing, Polym. Bull., 2013, 70, 467-748.

A. M. Elmér, P. Jannasch, J. Polym. Sci., Part A: Polym. Chem., 2006, 44, 2195-2205.

H. Yang, M. Yan, S. Pispas, G. Zhang, Macromol. Chem. Phys. 2011, 212, 2589-2593.

S. Kéki, J. Török, G. Deak, M. Zsuga, Eur. Polym. J., 2005, 1478-1483.

Oligomers have been reported from $p$-tert-butylphenol/ $\mathrm{KHCO}_{3}$ initiating system. ${ }^{51}$

Simultaneous copolymerization refers to polymerizations where both comonomers are introduced/copolymerized at the same time. To our knowledge, only one EC/comonomer (namely CL) truly sequential copolymerization has been reported. ${ }^{43}$

C. K. Williams, L. E. Breyfogle, S. K. Choi, W. Nam, V. G. Young, M. A. Hillmyer, W.

B. Tolman, J. Am. Chem. Soc., 2003, 125, 11350-11359.

B. M. Chamberlain, M. Cheng, D. R. Moore, T. M. Ovitt, E. B. Lobkovsky, G. W. Coates, J. Am. Chem. Soc., 2001, 123, 3229-3238.

L. R. Rieth, D. R. Moore, E. B. Lobkovsky, G. W. Coates, J. Am. Chem. Soc., 2002, 124, 15239-15248. 
57 W. Guerin, M. Helou, J.-F. Carpentier, M. Slawinski, J.-M. Brusson, S. M. Guillaume, Polym. Chem., 2013, 4, 1095-1106.

W. Guerin, M. Helou, M. Slawinski, J.-M. Brusson, J.-F. Carpentier, S. M. Guillaume, Polym. Chem., 2014, 5, 1229-1240.

59 W. Guerin, M. Helou, M. Slawinski, J.-M. Brusson, S. M. Guillaume, J.-F. Carpentier, Polym Chem., 2013, 4, 3686-3693.

60 C. G. Jaffredo, J.-F. Carpentier, S. M., Macromol Rapid Commun. 2012, 33, 1938-1944.

61 C. G. Jaffredo, J.-F. Carpentier, S. M., Polym Chem. 2013, 4, 837-850.

62 C. G. Jaffredo, J.-F. Carpentier, S. M., Macromolecules, 2013, 46, 6765-6776.

63 C. Guillaume, J.-F. Carpentier, S. M. Polymer, 2009, 50, 5909-5917.

64 C. Guillaume, N. Ajellal, J.-F. Carpentier, S. M. Guillaume, J. Polym. Sci., Part A: Polym. Chem. 2011, 49, 907-917.

65 M. Helou, G. Moriceau, Z. W. Huang, S. Cammas-Marion, S. M. Guillaume, Polym. Chem. 2011, 2, 840-850.

66 N. Ajellal, J.-F. Carpentier, C. Guillaume, S. M. Guillaume, M. Helou, V. Poirier, et al., Dalton Trans. 2010, 39, 8363-8376.

67 S. M. Guillaume, J.-F. Carpentier, Catal. Sci. \& Technol., 2012, 2, 898-906.

68 M. Helou, O. Miserque, J.-M. Brusson, J.-F. Carpentier, S. M. Guillaume, Chem. Cat. Chem. 2010, 2, 306-313.

69 M. Helou, O. Miserque, J.-M. Brusson, J.-F. Carpentier, S. M. Guillaume, Macromol. Rapid Commun., 2009, 30, 2128-2135.

70 S. Agarwal, M. Puchner, Eur. Polym. J., 2002, 38, 2365-2371.

71 S. Agarwal, N. Naumann, X. Xie, Macromolecules 2002, 35, 7713-7717.

72 T. Ariga, T. Takara, T. Endo, J. Polym. Sci. Part A 1993, 31, 581-584.

73 M. Helou, O. Miserque, J.-M. Brusson, J.-F. Carpentier, S. M. Guillaume, Chem. - A Eur. J., 2010, 16, 13805-13813.

74 P. Brignou, J.-F. Carpentier, S. M. Guillaume, Macromolecules, 2011, 44, 5127-5135.

75 P. Brignou, G. M. Priebe, O. Casagrande, J.-F. Carpentier, S. M Guillaume, Macromolecules, 2010, 43, 8007-8017.

76 A. Duda A, A. Kowalski, in Handbook of Ring-Opening Polymerization, Eds P. Dubois, O. Coulembier, J.-M. Raquez, Weinheim, Wiley-VCH Verlag GmbH \& Co., 2009, 1-51.

77 The experimental molar mass values -as determined by SEC using polystyrene standards of hydrodynamic radius possibly different from those of the EC/lactones or EC/lactide copolymers- did not vary steadily with the conversion of both comonomers, an observation for which we cannot provide a reasonable explanation at the present time.

Note that the ${ }^{13 \mathrm{C}}\left\{{ }^{1} \mathrm{H}\right\}$ NMR spectra were recorded with a relaxation delay of $10 \mathrm{~ms}$. Although not strictly quantitative, the amount of carbon atoms corresponding to a given resonance can thus be roughly hinted by the relative integration value of the signals. Note that such $\mathrm{P}(\mathrm{EC}-\mathrm{co}-\mathrm{VL})$ random copolymers were previously reported but no NMR data were given for comparison to the present spectra. ${ }^{44}$

80 N. Ajellal, M. Bouyahyi, A. Amgoune, C. M. Thomas, A. Bondon, I. Pillin, Y. Grohens, J.-F. Carpentier, Macromolecules, 2009, 42, 987-993. 